(Gdańsk)

\title{
Silty polskie pod Zbarażem 10 lipca 1649 roku
}

\begin{abstract}
The article presents the size and composition of the Polish forces near Zbaraż, with a breakdown into individual regiments and banners, at the beginning of the fights that began on 10 July 1649. In addition to repeating and arranging what was already known, many new findings have been introduced and errors contained in older literature have been corrected.
\end{abstract}

Zagadnieniem składu i liczebności sił polskich broniących obozu pod Zbarażem zająłem się kilka lat temu, ${ }^{1}$ niestety nie znałem wtedy podstawowego do ustalenia składu pułków dokumentu, jakim jest „Liqvidatia Woisk Rzptej na Commissiey Lubel(skiey) 1650” („Liqvidatia”) - uznaję je za podstawowe, gdyż jest to jedyne źródło bezpośrednie, które wymienia poszczególne chorągwie w pułkach. Popełniłem wtedy również kilka błędów i w rezultacie ten fragment mojej pracy okazał się gorszy, niż mógłby być. Niedokładności w nim popełnione wpłynęły też negatywnie na treść reszty pracy.

W niniejszym artykule postarałem się o jak najdokładniejsze przedstawienie tej kwestii. Nie ma w nim zbyt wiele polemiki, gdyż autorzy powstałych dotąd opracowań na temat oblężenia Zbaraża samą liczebnością i składem sił polskich nie zajęli się w sposób właściwy. I tak, piszący opracowania przed II wojną światową, bazując na niezbyt precyzyjnym w tej kwestii Wespazjanie Kochowskim, po prostu przepisali bezkrytycznie podany przez

\footnotetext{
1 Marek Rogowicz, Bitwa pod Zbarażem 1649 (Oświęcim: Napoleon V, 2013), 43-58.

2 Biblioteka Uniwersytetu Wrocławskiego (dalej: BUWr.), Steinwehr II F 37 vol. 2, Akc 1949, 440, Liqvidatia Woisk Rzptej na Commissiey Lubel(skiey) 1650, Lublin, 1650 r., 431v-432.
} 
niego skład sił polskich. ${ }^{3}$ Edward Kotłubaj, który prawdopodobnie zrobił to pierwszy, w niewydanym rękopisie, który przypuszczalnie był brudnopisem przyszłego opracowania, dopisał do podanych przez Kochowskiego oddziałów wyimaginowane liczby. ${ }^{4}$ Ksiądz Ludwik Frąś, ${ }^{5}$ znający zarówno pracę Kochowskiego, jak i poemat Wojciecha Radwańskiego, ${ }^{6}$ zupełnie zignorował w tej kwestii Radwańskiego, przepisując jedynie skład podany przez Kochowskiego. Warto jednak zauważyć, że przed wojną dokonano odkrycia bardzo istotnego dokumentu pomocnego do poznania składu sił polskich, jakim jest „Zapłata Woyskom Je ${ }^{\circ}$ Krolewskiey Mci y Rzptey na Comissiey Lubelskiey pro die Quinta Marty Anni MDCL. Podług Constitiey Sejmu Walnego Warszawskie ${ }^{\circ}$ Roku MDCXXXX Dziewiątym Odprawionego złożona” („Zapłata”). ${ }^{7}$ Część tego źródła została też wtedy opublikowana. ${ }^{8}$ Niestety historycy piszący przed i po wojnie nie wykorzystali całego dokumentu. Jedynie ogólnikowego podsumowania liczb tam zawartych z podaniem ilości chorągwi dokonał Jan Wimmer. ${ }^{9}$ Niestety jego zestawienie nie jest zbyt precyzyjne w stosunku do liczebności jazdy. Spośród niej jedynie podana przez niego liczebność husarii zgadza się z sumą koni $\mathrm{w}$ chorągwiach husarskich wymienionych w tym dokumencie, a o których wiadomo, że broniły Zbaraża. Pozostałe liczby mniej lub bardziej rozmijają się z zachowanymi danymi źródłowymi. Trafnie została podana jeszcze liczebność polskiej piechoty prywatnej i niemieckiej państwowej. Wimmer, choć wskazał poprawną liczbę, to jednak błędnie stwierdził udział w obro-

\footnotetext{
3 Annalium Poloniae ab obidu Vladslai IV. Climacter Primus. Scriptore Vespasiano a' Kochow Kochowski (Cracoviae: ex officina Georgii et Nicolai Schedel, po 3 II 1683), 117-118.

4 Biblioteka Polskiej Akademii Umiejętności i Polskiej Akademii Nauk w Krakowie (dalej: BPAU/PAN w Krakowie), rkps 1404/III, Edward Kotłubaj, „Dzieje wojenne Polski od wprowadzenia wiary chrześcijańskiej do ostatniego rozbioru”, t. 3, 49-52. Niektóre liczby z tekstu Kotłubaja przywołał Mirosław Nagielski w przypisach do pracy: Mirosław Nagielski, Relacje wojenne z pierwszych lat walk polsko-kozackich powstania Bohdana Chmielnickiego okresu „Ogniem i mieczem” (1648-1651) (Warszawa: „Viking”, 1999), 162-167.
}

5 Ludwik Frąś, Obrona Zbaraża w r. 1649 (Kraków: b.w., 1932), 23-24.

$6 \quad$ Wojciech Radwański, Zbaraska Expeditia Poważna y Sławna. \& Oblężenie Zbaraskie Niestychane zdawna. Przez iednego z Radwanów, y Herbu Radwanu, Podana do wiadomości wszelakiego Stanu (Warszawa: b.w., 1649).

7 Archiwum Główne Akt Dawnych w Warszawie (dalej: AGAD), Akta Skarbowe Wojskowe (dalej: ASW), dz. 86, nr 39, Zapłata Woyskom Je ${ }^{\circ}$ Krolewskiey Mci y Rzptey na Comissiey Lubelskiey pro die Quinta Marty Anni MDCL. Podług Constitiey Sejmu Walnego Warszawskie ${ }^{\circ}$ Roku MDCXXXX Dziewiątym Odprawionego złożona (dalej: Zapłata Woyskom), Warszawa, 5 III $1650 \mathrm{r}$.

8 Adam Sawczyński, „Płaca pocztom panięcym w 1650,” Przegląd Historyczno-Wojskowy (dalej: $P H W$ ) 9, z. 1 (1936): 119-125.

$9 \quad$ Jan Wimmer, Wojsko polskie w drugiej połowie XVII wieku (Warszawa: Wyd. Ministerstwa Obrony Narodowej, 1965), 63-64. 
nie regimentów niemieckich obu Przyjemskich, Krzysztofa i Zygmunta, gdy tymczasem brał w niej udział jedynie ten pierwszy. Niestety kolejni autorzy publikacji dotyczących obrony Zbaraża bezkrytycznie potraktowali to podsumowanie, przepisując je lub parafrazując bezrefleksyjnie, co czyni polemikę z ich stwierdzeniami w tej kwestii bezprzedmiotową ${ }^{10}$ Wyjątkiem jest artykuł Bartosza Staręgowskiego, który zajął się składem i liczebnością zaciągów wielkopolskich uczestniczących w bitwie. ${ }^{11}$

Poniżej przedstawiłem skład czterech pułków, na jakie dzieliło się wojsko zbaraskie. Chorągwie wchodzące w skład trzech z nich (dowodzonych przez regimentarzy) wraz $\mathrm{z}$ nazwiskami poruczników zostały ustalone głównie na podstawie „Liqvidatii”. Warto parę słów poświęcić strukturze dokumentu. Dzieli się on na 4 części, w których wymienione są chorągwie, często wraz z liczebnością. Te części to kolejno: „Naprzód Poczty Panięce”, „Woisko Korsuńskie”, „Woisko Żbaraskie” i „Woisko Zborowskie”.

Większość wojsk prywatnych została wymieniona na początku dokumentu w części „Naprzód Poczty Panięce”. Doszło przy tym do powtórzenia, bo w części „Woisko Żbaraskie” ponownie wymieniono, już w konkretnym pułku, chorągiew kozacką wojewody kijowskiego Adama Kisiela. O tym, że wymienione we fragmencie „Naprzód Poczty Panięce” oddziały wchodziły głównie w skład wojska zbaraskiego, dowiadujemy się z "Zapłaty", gdzie stwierdzone jest przyznanie dla większości z tych chorągwi ćwierci „darownych" będących dodatkiem do żołdu należnym oddziałom broniącym Zbaraża. Utrudnieniem dla badaczy jest to, że część oddziałów magnackich broniących Zbaraża nie dostała żołdu „darownego". Były to wszystkie chorągwie wołoskie, tatarskie, a także dragońskie i piesze. ${ }^{12} \mathrm{Wy}-$ jątkiem jest chorągiew „dragańska” (dragońska) starosty krakowskiego Jerzego Lubomirskiego pod wodzą Samuela Grotkowskiego, która otrzymała dwa miesiące „darowne". ${ }^{13}$ Wymienione w podanym fragmencie "Liqvidatii” wojska prywatne doliczyłem do pułków, w których „Liqvidatia” wymienia oddziały państwowe tychże magnatów. Prywatne oddziały regimentarzy Stanisława Lanckorońskiego i Mikołaja Ostroroga wymienione w „Zapłacie” dopisałem do ich pułków. Liczebność oddziałów zaciężnych i prywatnych

10 M.in.: Kacper Śledziński, Zbaraż 1649 (Warszawa: Bellona, 2005), 26-28; Dariusz Andrzejczak, Kampania zbaraska 1649 roku (Toruń: Adam Marszałek, 2012), 85-106.

11 Bartosz Staręgowski, „W służbie województwom wielkopolskim i Rzeczypospolitej. Okoliczności sformowania i działalności pułku Bogusława Leszczyńskiego w latach 1648-1649," Res Historica, nr 44 (2017): 33-61, http://dx.doi.org/10.17951/rh.2017.44.33-61.

12 O tym, jakim oddziałom przyznano lub nie żołd darowny: Archiwum Państwowe w Gdańsku (dalej: AP w Gdańsku), Recesy Stanów Zachodnio-Pruskich (dalej: RSZP), sygn. 300.29.133, Script ad Archivum na Seymie 1649 d(ie) 22 Novembris od Stanów Koronnych podany, Warszawa, 22 XI 1649 r., 443-444.

13 AGAD, ASW, dz. 86, nr 39, Zapłata Woyskom, 40v-41. 
ustaliłem głównie na podstawie „Zapłaty”. Nie dotyczy to jedynie oddziałów wielkopolskich.

W części „Woisko Żbaraskie” „Liqvidatia” wymienia zarówno zaciężne, jak i niektóre prywatne oddziały wchodzące w skład poszczególnych pułków. Niestety skład pułków zbaraskich podano z dołączeniem do nich niektórych oddziałów, które pod Zbarażem nie walczyły. Tak jest na pewno w przypadku chorągwi Liniewskiego ${ }^{14}$, która została podana w dwóch miejscach - w wykazie oddziałów zbaraskich i zborowskich. Warto dodać, że w pułku Andrzeja Firleja jest wyszczególniona od 1 października 1648 r. do 1 kwietnia 1649 r. W pułku Mikołaja Ostroroga jest z kolei wymieniona chorągiew Tomasza Humieckiego, a zaraz potem w pułku podolskim. Ta jednak z pewnością nie broniła Zbaraża, gdyż nie dostała ćwierci „darownych", które by jej za to przysługiwały, a jedynie trzy ćwierci żołdowe od 1 lipca 1649 r. do 1 marca 1650 r. Do tego otrzymała jeszcze ćwierć „,darowną" kamieniecką i żołdową za kwartał zaczynający się 1 stycznia 1649 r. ${ }^{15}$

Istotną różnicą między „Zapłatą” (k. 40v) a „Liqvidatią” jest kwestia właściciela chorągwi prywatnej dowodzonej przez rotmistrza Marcina Oleśnickiego. Według tego pierwszego dokumentu należała ona do chorążego koronnego Aleksandra Koniecpolskiego, według „Liqvidati” do starosty kałuskiego Jana Zamoyskiego. Wątpliwości w tej mierze rozstrzyga jeden z poematów rycerskich, który wymienia ją także wśród oddziałów Zamoyskiego. ${ }^{16}$

Wiele szczegółów ustaliłem dzięki innym dokumentom. Księgi grodzkie lubelskie za lata 1648-1649 pozwoliły zidentyfikować przypuszczalnych poruczników następujących chorągwi: stolnika bracławskiego Jana Baranowskiego, Stefana Komorowskiego, strażnika koronnego Aleksandra Zamoyskiego, potwierdzić dane porucznika chorągwi Jerzego Hołuba, ustalić imię rotmistrza Mikołajewskiego - Andrzej. ${ }^{17}$ "Instructia Ich Mosciom Panom" wymienia imiona i nazwiska poruczników chorągwi husarskich sta-

14 Imienia tego rotmistrza nie udało mi się ustalić. Podobnie rzecz się ma $\mathrm{z}$ wieloma innymi oficerami - dotyczy to tych, których imion nie podałem. Gdy imiona są w nawiasach, oznacza to, że nie zostały podane w tym konkretnym źródle, na które się powołuję.

15 AGAD, ASW, dz. 86, nr 39, Zapłata Woyskom, 29v.

16 Katafalk Rycerski Wielmożnemu Jego Mośći Panu Mikołaiowi z Dambrowice Firleiowi Starościcowi Trembowelskiemu, Rotmistrzowi I. K. M (B.M.W: b.w., b.d.w.), 139.

17 Archiwum Państwowe w Lublinie (dalej: AP w Lublinie), Zespół 8: Relationes (dalej: Zespół 8), sygn. RMO 76, W Xiężomyszey w ktorey Pana Strażnikowa Chorągiew die decima quinta Novembris [1648] stanęła te szkody poczyniła, Lublin, [po 15 XI 1648 r.], 695-695v; RMO 77, Maidan \& HałtunsaryP rotestatur, Lublin, [po 30 XII 1648 r.], 16v-17v; Wyrzynska Protestatur, Lublin, [po 2 XI 1648 r.], 26v-29; Regestr Szkod przez Żołnierstwo Je ${ }^{\circ}$ Mści Pana Stephana Komorowskiego oddanym wsi Skokowa poczynionych, Lublin, [po 16 XII 1648 r.], 32-34v; Regestr krzywd y Szkod Poddanym wsi Suchodoł y Siedliska Jeo Mści Pana Suchodolskiego przez Companią Chorągwi Jeo Mści Pana Hołuba w Poniedziałek y Wtorek po Święcie Świętego Marcina blisko przeszłym bliszsze poczynionych, Lublin, [po 17 
rosty łomżyńskiego Hieronima Radziejowskiego, kasztelana kamienieckiego Stanisława Lanckorońskiego, koniuszego koronnego Michała Aleksandra Lubomirskiego i starosty lwowskiego Adama Hieronima Sieniawskiego. W jednej z kopii tego dokumentu pojawiają się błędy. Daniel Puzowski miał być wg tej wersji porucznikiem u Sieniawskiego, a Aleksander Ludwik Niezabitowski u Lubomirskiego - $\mathrm{w}$ istocie było na odwrót. ${ }^{18}$ Między innymi „Liqvidatia” wymienia Niezabitowskiego jako porucznika u Sieniawskiego.

W tym miejscu warto bliżej przedstawić podstawy źródłowe dla ustalenia składu kolejnych pułków. W pułku Firleja „Liqvidatia” wymienia oprócz oddziałów zaciężnych jeszcze prywatną chorągiew kozacką starosty nowogrodzkiego, którym był Jan Piaseczyński. Husarska, wg tego dokumentu, rota Andrzeja Sierakowskiego w "Zapłacie” została nazwana arkebuzerską, w istocie jako husarska przy wypłacie została potraktowana identycznie jak druga - arkebuzerska/rajtarska tegoż rotmistrza. Warto dodać, że również Kochowski określa chorągiew Sierakowskiego jako husarską. ${ }^{19}$ Jak zobaczymy dalej, w kwestii określenia rodzaju oddziału, „Liqvidatia” jest bardziej trafna od „Zapłaty”, w której dopuszczono się wielu uproszczeń. Wszystkie wymienione przez autora „Liqvidatii” w tym pułku oddziały zaciężne otrzymały wg „Zapłaty” cztery ćwierci „darowne”, a prywatna Piaseczyńskiego także cztery.

W efekcie mamy ustalony skład pułku Firleja z wyjątkiem oddziałów wielkopolskich, które w "Liqvidatii” zostały podane jedynie ogólnikowo (1250 koni arkebuzerów, 550 koni dragonów i 400 piechoty odesłanej do Kamieńca Podolskiego). Podobnie ogólnikowo - identycznie jak w „Liqvidatii” - siłę tych oddziałów określono w konstytucjach sejmowych. ${ }^{20}$

Oddziały wielkopolskie to cała wymieniona w pułku Firleja arkebuzeria, regiment dragoński Jacka Rozrażewskiego/Rozdrażewskiego, rajtarzy Krzysztofa Unruka i dragoni Albrechta Smoguleckiego. Listę nazwisk rotmistrzów wielkopolskich i planowaną siłę ich chorągwi ustaliłem głównie na podstawie uchwały sejmiku w Środzie (Wielkopolskiej) z 17 grudnia $1648 \mathrm{r}$.

XI 1648 r.], 48-55; Ex parte Wyrzynska \& Stawskich Relatio, Lublin, b.d. [zapewne koniec 1648 r.], 74-75. Piszę „przypuszczalnych”, gdyż dane na ich temat pochodzą z końca 1648 r.

18 AP w Gdańsku, RSZP, sygn. 300.29.133, Instructia Ich Mosciom Panom, Lwów, [przed 22 XI 1649 r.], 322. Wspomniana, błędna miejscami, ale lepiej znana historykom wersja tego dokumentu w: Львівська національна наукова бібліотека імені В. Стефаника НАН України (dalej: ЛНБВС), Oddział Rękopisów (dalej: OR), fond (dalej: f.) 5, opis (dalej: o.) 1, Rękopisy Biblioteki Zakładu Narodowego im. Ossolińskich (dalej: RBZNiO), sygn. II 225, Instructia od Woyska Ich Mciom PP. Posłom, Lwów, przed 22 XI 1649 r., 287v-293.

19 Annalium Poloniae, 117.

20 Konstitvcie seymv walnego koronnego sześćniedzielnego, warszawskiego Roku Pańskiego MDC.XLIX. Dnia 22 listopada (Warszawa: W Drukarniey Piotra Elerta J. K. M. Typographa, 1649), 21-22. Nie wspomniano tu jednak o odesłaniu piechoty do Kamieńca. 
i komputu uchwalonego na sejmie koronacyjnym. ${ }^{21}$ Są między nimi dwie różnice - w uchwale sejmikowej zamiast roty Krzysztofa mamy Wojciecha Pigłowskiego. O tym, że pod Zbarażem była jednak chorągiew Krzysztofa, dowiadujemy się z jednego z diariuszy oblężenia przy opisie walk 13 lipca. ${ }^{22}$ Wiadomo również o udziale w walkach kompanii Jarosza (czyli Hieronima) Pigłowskiego, która została wymieniona wśród oddziałów uczestniczących w podjeździe poprzedzającym bitwę, w trakcie którego doszło do starcia w dniu 9 lipca pod Czołchańskim Kamieniem. ${ }^{23}$ Tak więc Krzysztof musiał zastąpić właśnie Wojciecha Pigłowskiego. Oprócz tego żadne ze źródeł nie wymienia chorągwi Konstantego Opalińskiego pod Zbarażem, można natomiast znaleźć wzmiankę o udziale w walkach 13 lipca chorągwi generała wielkopolskiego ( $\mathrm{tj}$. starosty generalnego wielkopolskiego) Bogusława Leszczyńskiego. ${ }^{24}$ Wcześniej ta chorągiew z porucznikiem Władysławem Kłodzińskim została wymieniona na podjeździe zakończonym bitwą pod Sulżyńcami 31 maja - 1 czerwca. ${ }^{25}$ Dokumenty z akt grodzkich poznańskich pozwoliły na sprecyzowanie imion niektórych rotmistrzów wielkopolskich - tych, które zostały pominięte w dwóch wyżej wymienionych

${ }^{21}$ Biblioteka XX. Czartoryskich w Krakowie (dalej: B. Czart.), rkps 1774, Lauda średzkie i poznańskie województw poznańskiego i kaliskiego, oblatowane w grodzie poznańskim w latach 1601-1703 (dalej: rkps 1774), Laudum Woiewodztw Wielkopolskich na Seymiku Srzedzkim, Środa Wielkopolska, 17 XII 1648 r., 215-216; AGAD, ASW, dz. 86, nr 37, Comput Woyska Supplementoweo Z Ordinatiey Seymu Coronationis Ao 1649, b.m., b.d., 50-53; Comput Woyska Supplementowe ${ }^{\circ}$ Z Ordinatiey Seymu Coronationis $A^{\circ} 1649$. Dwie inne wersje tegoż komputu wraz z poprzedzającym go komputem wojska kwarcianego znajdują się w: B. Czart., rkps 144, Teka Naruszewicza, tom 144 (dalej: rkps 144), 791-797 i w BUWr, Steinwehr II F 37 vol. 2, Akc. 1949, 440, 316v-317.

22 „Akta Anni 1649 pod Zbarażem Nowym albo raczej diariusz w miesiącu lipcu za regimentu jm. pana Andrzeja z Dąbrowice Firleja kasztelana natenczas bełskiego, jm. pana Stanisława z Brzezia Lanckorońskiego kasztelana kamienieckiego, jm. pana Mikołaja Ostroroga podczaszego koronnego," w Nagielski, Relacje wojenne, 138.

23 „Relacyja expedycyjej zbaraskiej w roku Pańskim 1649 przeciw Chmielnickiemu rytmem polskim przez Marcina Kuczwarewica roku Pańskiego 1650 przełożona. W Lublinie, w drukarni Jana Wieczerkowicza, w „Arma cosacica”. Poezja okolicznościowa o wojnie polsko-kozackiej 1648-1649, oprac. Piotr Borek (Kraków: Collegium Columbinum, 2005), 183, wiersze 331-338.

24 „Akta Anni 1649 pod Zbarażem Nowym,” 138.

25 AP w Gdańsku, RSZP, sygn. 300.29.133, Copia listu Je ${ }^{\circ}$ Mci P. Krystofa Przyiemskiego Do Jego Mci Xdza Podkanclerzego Koronnego, z Pod Zasławia z obozu 2 Juny 1649, 65. Nazwisko porucznika podaje także Kochowski w Annalium Poloniae, 114, 117. Datę 31 maja podaje: ЛНБВС, OR, f. 5, o.1, RBZNiO, sygn. II 225, Copia Listu od Je ${ }^{\circ}$ Mci Pana Bełskiego do KJM 2 Mensis Junii [1649] z pod Zasławia, 220v-221; a 1 czerwca Marcin Kuczwarewicz, „Relacyja ekspedycjej zbaraskiej w roku Pańskim 1649 przeciw Chmielnickiemu rytmem polskim przez Marcina Kuczwarewica roku Pańskiego 1650 przełożona," w Arma Cosacica, 176 (dopisek z datą przy wierszach 75-80). 
dokumentach: Andrzeja Skórzewskiego, Wojciecha Jastrzębskiego, Wojciecha Kobierzyckiego, Piotra Tomickiego, Albrechta Smoguleckiego i Mikołaja Pogórskiego. ${ }^{26}$ Dokumenty sporządzone przy rozliczaniu oddziałów, a wskazane w artykule Staręgowskiego pozwoliły na potwierdzenie powyższych danych, a także ustalenie składu etatowego oddziałów wielkopolskich, niektórych poruczników jazdy oraz oficerów regimentu Rozrażewskiego. Są w nich pewne rozbieżności, gdyż najpierw Kłodziński przysięga za regestrem, że miał 150 koni, a przy podsumowaniu tegoż wychodzi 159 koni wg pocztów (licząc z 5 muzykami, kapelanem i cyrulikiem), spośród 100 koni Stanisława Dębińskiego 1 uciekł, u Pogórskiego wraz z muzykami (5 koni) wychodzi 109 koni, u Krzysztofa Pigłowskiego z muzykami (5 koni) 111, u Jastrzębskiego 98 (bo jeden poczet przysłany w zastępstwie innego w sile 2 koni nie dogonił na czas chorągwi), Kobierzyckiego 98, Mycielskiego 97, Skórzewskiego 93, Tomickiego $79 .{ }^{27} \mathrm{~W}$ sumie w dziewięciu chorągwiach, dla których podano regestra, mamy 943 zamiast podanych w podsumowaniach 921. Nie można jednak wykluczyć, że w regestrach są podane osoby, które ubyły przed obroną Zbaraża i faktycznie było pod chorągwiami w obozie tylu ilu podali dowódcy oddziałów. Ich przekaz traktuję zatem jako podstawę do ustalenia liczebności (tak samo zrobił już wspomniany Staręgowski). Według tych rozliczeń Smogulecki przyprowadził dragonów zamiast arkebuzerów.

Warto wspomnieć, iż wg Wojciecha Radwańskiego pod Zbarażem znaleźli się nie tylko dragoni Smoguleckiego, ale i jego arkebuzerzy. ${ }^{28}$ Skąd się tam zatem wzięli? Jeszcze w grudniu 1648 r. w skład pułku Firleja wchodziły trzy chorągwie starosty międzyrzeckiego Franciszka Sędziwoja Czarnkowskiego po 100 koni każda (kozacka, rajtarska, dragońska). ${ }^{29}$ Wiadomo również, że Albrycht Smogulecki był rotmistrzem tegoż starosty i nie dotarł ze swą chorągwią pod Piławce. ${ }^{30}$ Nie jestem zatem pewien, czy można

26 Archiwum Państwowe w Poznaniu (dalej: AP w Poznaniu), Księgi grodzkie poznańskie (dalej: KGP), sygn. Gr. 693, Oblata literarum Conuentus Posnanień, Poznań, 8 VI 1648 r., 464v-465; Oblata Lustrationis Militum, Kalisz, 28 lipca [1648 r.], 628; Protestatur Czarnkowski, b.m., b.d., 786-787; sygn. Gr. 694, Oblata Literarum Ser \& Regi \& Mtis pro pote Pogorski Ad Officium \& Acta praesentia Castren Posnanien, Warszawa, 14 V 1649 r., 946v-947v. Księga dostępna w Internecie, dostęp luty 24, 2019, http://szukajwarchiwach.pl/53/20/0/-/ Pozna\%C5\%84\%20Gr.693/str/1/1/15\#tabSkany.

27 AP w Poznaniu, Komisja Skarbowa Poznańska, sygn. 1, Acta Comissionis 1650, 6-16v, $18-19 v, 21-22,26-29 v, 31 v, 36-36 v, 75-86 v$.

28 Radwański, Zbaraska Expeditia, Cv.

29 B. Czart., rkps 398, Rosporzondzenie woyska koronnego przes Jaśnie Oświeconego Xiążęcia IMsć Wiśniowieckiego wojewody Ruskiego do we Lwowie Prima Octobris zaciągnione a teraz na Stanowiska rozłożone d. 14 Decembris. Anno Dni 1648, Lwów, 12 XII 1648 r., 74-75.

30 AP w Poznaniu, KGP, sygn. Gr. 693, Protestatur Czarnkowski, b.m., b.d., 786-787. 
wykluczyć udział chorągwi arkebuzerskiej Smoguleckiego. Radwańskiemu zdarzyły się jednak błędy w wyliczeniu składu sił polskich, więc do rozstrzygnięcia tej kwestii potrzebne byłoby niezależne źródło. Wydaje się jednak, że bardziej prawdopodobny jest brak arkebuzerów Smoguleckiego w bitwie, tym bardziej że w swym wyliczeniu Radwański pominął arkebuzerów generalskich i Stanisława Dembińskiego.

Warto dodać, że skład pułku Firleja ulegał przed obroną pewnym zmianom. Przykładowo Marcin Kuczwarewic wymienia chorągwie Aksaków w pułku Firleja na podjeździe pod Chłapotyń, który miał miejsce 5 czerwca. ${ }^{31}$ Tymczasem podczas walk zbaraskich chorągwie te znalazły się w pułku Ostroroga. Z kolei chorągiew husarska księcia Karola Koreckiego i kozacka starosty nowogrodzkiego Jana Piaseczyńskiego dołączyły do pułku dopiero 19 czerwca pod Zasławiem. ${ }^{32}$

Przy zestawieniach oddziałów pojawiają się znaki „*” i „^”. Pierwszy oznacza, że chorągiew, choć niekoniecznie we właściwym pułku, wymienił Kochowski, a drugi, że znajduje się ona w ogólnym zestawieniu Radwańskiego. Nieobecnych oficerów zaznaczyłem znakiem „(-)”.

Ogółem w skład pułku Andrzeja Firleja, kaszt. bełskiego ${ }^{33}$ wchodziły 43 chorągwie o sile 4252 koni i osób (etatową liczebność jazdy podawano w koniach, piechoty w osobach):

Husaria: 6 chorągwi, 525 koni

1. Jędrzeja Firleja, kaszt. bełskiego, por. Michał $\operatorname{cada}^{34} 100$ koni (100)s s

2. Jerzego Lubomirskiego, star. krakowskiego (-), por. Krzysztof Rajecki ${ }^{35}$, po nim por. Niepokuczycki 100 koni $(100) \mathrm{k}^{\star \wedge}$

31 „Relacyja expedycyjej zbaraskiej,” 178, wiersz 154.

32 Biblioteka Zakładu Narodowego im. Ossolińskich (dalej: BZNiO), Manuscripta Instituti Ossoliniani (dalej: MIO), Collectio dr. A. Czołowski (dalej: CdAC), sygn. II 9538, Diariusz rzeczy w Woysku naszym ad Decima octava Juny [1649], b.m. [zapewne w drodze pod Zbaraż i obóz pod Zbarażem], [1649 r.], 3.

338 lipca do obozu dotarła już niepotwierdzona informacja o nominowaniu Firleja na wojewodę: BZNiO, MIO, CdAC, sygn. II 9538, Diariusz rzeczy w Woysku naszym ad Decima octava Juny, b.m., b.d., 5: „Udawano ale opacznie iakoby P. Bełskiemu Woiewudztwo Sędomirskie przyniesiono".

34 Imię porucznika uzupełniłem z dokumentu dotyczącego zapłaty żołdu za pierwszą ćwierć 1649 r. dla chorągwi, których rotmistrzem był Firlej: AGAD, ASK, dz. 86, nr 37, Rachunki Skarbowe z Chorągwiami Nowego zaciągu po Seimie Electionis którym ma się zaczynać służba A die 1a January A. 1649, b.m. [prawdopodobnie Warszawa], b.d., 34.

35 Według Kochowskiego (Annalium Poloniae, 117) i BUWr., Steinwehr II F 37 vol. 2, Akc. 1949, 440, Liqvidatia Woisk Rzptej na Commissiey Lubel(skiey) 1650, 431v-432, rotą Jerzego porucznikował Niepokuczycki. Tak zapewne było, ale dopiero po śmierci Rajeckiego, którego jako porucznika u Jerzego wymieniają: "Akta Anni 1649 pod Zbarażem Nowym,” 138; „Diariusz Ekspedycyjej Zborowskiej,” w Relacje wojenne, 178; ЛНБВС, OR, f. 5, о. 1, RBZNiO, sygn. II 225, Copia listu Pana Raieckiego Pułkownika Usarskiego Je ${ }^{\circ} \mathrm{MP}$. Generała 
3. Konstantego Lubomirskiego, star. sądeckiego (-), por. Borzewicki ${ }^{36}$

4. Hieronima Radziejowskiego, star. łomżyńskiego (-), por. Wojciech Ubysz

5. księcia Karola Koreckiego (-), por. Dangier 89 koni $(100) \mathrm{k}^{\star \wedge}$

6. Andrzeja Sierakowskiego, pisarza polnego kor., por. Charliński

Rajtaria: 2 chorągwie, 98 koni $(100) s^{\star \wedge}$

48 koni $(100) s^{\star \wedge}$

197 koni

1. Andrzeja Sierakowskiego, pisarza polnego kor., por. Jezierski (wg „Liqvidatii” Jezierzywski)

2. Krzysztofa Unruka vel Unruga ${ }^{37}$ Arkebuzeria: 10 chorągwi, 97 koni $(100) s^{* \wedge}$ 100 koni $(100) s^{\star \wedge}$ 1021 koni

1. Bogusława Leszczyńskiego, generała wielkopolskiego (-), por. Władysław Jan Kłodziński

$150 \mathrm{koni}$, *

2. Stanisława Dembińskiego (-), por. Stanisław Węgierski

3. Mikołaja Szczęsnego Pogórskiego

4. Krzysztofa Pigłowskiego

5. Wojciecha Kobierzyckiego

6. Wojciecha Jastrzębskiego

100 koni $(100) s^{\star}$

7. Franciszka Mycielskiego

8. Piotra Tomickiego (-), por. Wacław Stawski

100 koni $(100) s^{* \wedge}$

9. Andrzeja Skórzewskiego (-), por. Walerian Podleski

10. Jarosza (inaczej Hieronima) Pigłowskiego Kozacy: 8 chorągwi,

100 koni $(100) s^{\star \wedge}$

98 koni $(100) s^{* \wedge}$

100 koni $(100) s^{* \wedge}$

100 koni $(100) s^{\star \wedge}$

76 koni $(100) s^{* \wedge}$

97 koni $(100) s^{\star \wedge}$

1. Andrzeja Firleja, kaszt. bełskiego, por. Jan Butler ${ }^{38}$

100 koni $(100) s^{\wedge}$

759 koni

99 koni

Krakowskiego de data w Obozie 6 Juny [1649 r.], b.m., 225v oraz ЛНБВС, OR, f. 5, о. 1, RBZNiO, sygn. II 189, [notatka Marcina Golińskiego], Kazimierz, 30 X 1649 r., 290..

36 Według Kochowskiego porucznikiem był tu Rajecki (Annalium Poloniae, 117) - błąd Kochowskiego mógł wynikać stąd, że wcześniej Krzysztof Rajecki był porucznikiem u Konstantego - w rocie husarskiej zniesionej pod Korsuniem. Zob. AGAD, ASW, dz. 86, nr 39, Zapłata Woyskom, 7.

37 AGAD, ASW, dz. 86, nr 37, Comput Woyska Supplementowe ${ }^{\circ}$ Z Ordinatiey Seymu Coronationis $\mathrm{A}^{\circ} 1649$, b.m., b.d., 50-51; B. Czart., rkps 144, Komput woyska suplementowego z Ordynacyi Coronationis, b.m., 1649 r., 794; a także Radwański, Zbaraska Expeditia, C1, podają, że chorągwie Smoguleckiego i Unruka miały być rajtarskimi, jednak z uchwały sejmiku w Środzie (Wielkopolskiej) z 17 grudnia 1648 r.: B. Czart., rkps 1774, 215-216 (na s. 203 imiona niektórych rotmistrzów) i Constitucie seymu, 21 wynika, że były arkebuzerskimi. Nazwy te często stosowano zamiennie. Tu sprawę rozstrzygają przywołane wcześniej wyliczenia skarbowe poznańskie.

38 „Komput długu wojska podany na Sejm przez Komissarzów. Lwów 23 Września 1649,” w Jakuba Michałowskiego wojskiego lubelskiego, a później kasztelana bieckiego Księga Pamiętnicza (Kraków: Cesarsko-Królewskie Towarzystwo Naukowe Krakowskie, 1864), 494. 
2. Jana na Żorniszczach Piaseczyńskiego, podkom. nowogrodzkiego

93 konie $(100) s^{*}$

3. Jana na Kuninie Piaseczyńskiego, star. nowogrodzkiego ${ }^{39}$, por. Chlebowski

4. Łukasza Hulewicza, starosty zwinogrodzkiego

5. Zachariasza Czetwertyńskiego, starosty raciborskiego (-)

98 koni, $\mathrm{p}^{*}$

92 konie $(100) s^{\star \wedge}$

76 koni $(100) s^{\star \wedge}$

6. Mikołaja Kazimierza Kossakowskiego, podsędka bracławskiego, por. Kossakowski

113 koni $(100) s^{\star \wedge}$

7. Romana Zahorowskiego, stolnika czernichowskiego 100 koni $(100) \mathrm{s}^{\wedge}$

8. Jerzego Hołuba, por. Samuel Hołub Dragonia: 10 kompanii, 88 koni $(100) \mathrm{k}^{* \wedge}$ 1050 koni

1. regiment Stefana Oborskiego, star. liwskiego (-), 3 kompanie ${ }^{40}$

2. Marcina Czarneckiego, oboźnego wojskowego

3. regiment Jacka Rozrażewskiego, 5 kompanii ${ }^{41}$, razem
a. oberszter
b. obersztlejtnant Andrzej Reizer
c. kapitan Jakub Lemka,

300 koni $(300) s^{\star \wedge}$

100 koni $(100) s^{\wedge}$

550 koni $(550) s^{\wedge}$

92 konie

80 koni

148 koni

Chorągiew ta nie weszła ani w komput kwarciany, ani suplementowy. Żołd wyliczono jej jednak wraz z innymi chorągwiami zaciężnymi, gdyż została zaciągnięta na rozkaz króla po naradzie z senatem, a jej służba zaczęła się 1 stycznia - zob. BUWr, Steinwehr II F 37 vol. 2, Akc. 1949, 440, Comput tych, którym JKM. na nowy zaciąg ex Senaty Consulto służbę przypowiedzieć rozkazał, a die 1 January 1649, Żołd qvarciany naznaczywszy, b.m., b.d., $317 \mathrm{v}$. Takich chorągwi królewskich pominiętych w komputach zapewne było więcej, gdyż jak donosił listem z 3 lipca spod Zbaraża Ostroróg: „Drudzy narzekają że i służby nie są pewni; choć przypowiedne listy mają, w kompucie ich nie masz", zob. Ojczyste spominki w pismach do dziejów dawnéj Polski, diaryusze, relacye, pamiętniki i.t.p. służyć mogące do objaśnienia dziejów krajowych tudzież listy historyczne do panowania królów Jana Kazimiérza i Michała Korybuta oraz listy Jana Sobieskiego marszatka i hetmana wielkiego koronnego z rękopisów zebrane przez Ambrożego Grabowskiego, t. 2 (Kraków: Józef Cyper, 1845), 54.

39 Obaj Piaseczyńscy byli urzędnikami „Nowogrodku Siewierskiego”, zob. „Suffragia woiewodztw, y ziem koronnych, y wielkiego księstwa litewskiego, Zgodnie na Nayiaśnieyszego Iana Kazimierza, obranego Króla Polskiego, Wielkiego Xiążęcia Litewskiego, Ruskiego, Pruskiego, Mazowieckiego, Żmudzkiego, Inflantskiego, Smoleńskiego, Czerniechowskiego, etc. Y Szwedzkiego, Gotskiego, Wandalskiego, etc. Dziedzicznego Króla dane, między Warszawą, a Wolą, dnia 17 Listopada roku 1648," w Volumina Legum, t. 4, Przedruk zbioru praw staraniem xx. Pijarów w Warszawie, od roku 1732 do roku 1782, wydanego (Petersburg: Jozafat Ohryzko, 1860), 116. Tam podane są ich gniazda rodowe.

40 Zapewne dowodził nimi bliżej nieznany mi Majer, pod którego komendą widziano trzy kompanie dragońskie z pułku Firleja pod Kazimierzem idące z obozu 18 X 1649 r. - zob. ЛНБВС, ОR, f. 5, о. 1, RВZNiO, sygn. II 189, [Notatka Marcina Golińskiego], b.m., b.d., 289.

${ }_{41}$ Radwański, Zbaraska Expeditia, Cv. Mylnie podaje liczbę kompanii tego regimentu na 6 (a także Oborskiego na 3 i Przyjemskiego na 6). 

d. kapitan Jakub Bodke
e. kapitan Salomon Kindler

4. Wojciecha Albrychta Smoguleckiego

\section{Piechota niemiecka:}

1. regiment Krzysztofa Przyjemskiego, 6 kompanii 600 osób (600) $\mathrm{s}^{\star \wedge}$ Piechota polska:

1. Andrzeja Firleja, kaszt. bełskiego ${ }^{42}$
126 koni

104 konie

100 koni, $s^{\star \wedge}$

Zdaniem Kochowskiego chorągwie husarskie obu Lubomirskich były w pułku Lanckorońskiego (pozostałe podaje jak „Liqvidatia”), zamiast nich widzi tu husarzy Myszkowskiego (którzy wg „Zapłaty” zostali umieszczeni wśród chorągwi kozackich i dostali też żołd kozacki - po 31 florenów za ćwierć, więc stanowili zapewne chorągiew kozacką), arkebuzerskich wymienia u Firleja tylko 10, kozackich 8 (z tym, że zamiast chorągwi Firleja i Zahorowskiego podaje Różniatowskiego i Jana Strzyżowskiego), dragońskich ogólnie 9 pod wodzą Stefana Oborskiego i Smoguleckiego. ${ }^{43}$

Przejdźmy do pułku Lanckorońskiego. Według Radwańskiego w pewnym momencie (przed informacją o robieniu trzeciego wału i rozmieszczenia na nim, a zatem przed nocą z 19 na 20 lipca) „Pana Kamienieckiego/ y z Pułkiem Korfowym/ Posłali do Zbaraża". Radwański podał także liczbę kompanii w regimencie Mikołaja Korfa. Kochowski umieszcza regiment Korfa w pułku kasztelana kamienieckiego. ${ }^{44}$ Wreszcie wg "Liqvidatii” w tymże pułku byli rajtarzy Korfa. Na podstawie tego ostatniego źródła można określić pozostałe oddziały wchodzące w skład tego pułku, a na podstawie „Zapłaty” ich liczebność. Ten dokument podaje, że chorągwie kozacka pod wodzą Goszczyńskiego i dragońska pod wodzą Grotkowskiego należały do sił prywatnych starosty krakowskiego. ${ }^{45} \mathrm{~W}$ istocie jednak kozacka Goszczyńskiego określana jest w aktach grodzkich krakowskich jako chorągiew województwa krakowskiego, ${ }^{46} \mathrm{a} \mathrm{w}$ „Zapłacie” jest wspomniane,

42 AGAD, ASW, dz. 86, nr 39, Zapłata Woyskom, 34, nie wylicza żołdu „darownego” za Zbaraż dla tej roty, podaje dla niej jedynie zapłacone trzy ćwierci na 100 osób w każdej od 1 I do 30 IX 1649 r.

\section{Annalium Poloniae, 117.}

44 Radwański, Zbaraska Expeditia, B2, Cv; Annalium Poloniae, 117; Rogowicz, Bitwa pod Zbarażem, 123.

45 AGAD, ASW, dz. 86, nr 39, Zapłata Woyskom, 40v-41.

46 Archiwum Narodowe w Krakowie (dalej: AN w Krakowie), Akta Grodzkie Krakowskie (dalej: AGK), Relationes, nr 75, Regestr Statiey, iako wiele poddani Conventu krakowskiego, Zakonu Świętego Ducha, de saxia Statiey wydali z Wranina y z Wranica na Jego Mości Pana Stanisława czyli Stephana Rychlewskiego S skałmierza Stanowisko maiącego, którego Porucznikiem był Jego Mość Pan Franciszek Gościński, Kraków, 1648 r. [po powrocie spod Piławiec], 2143-2146; nr 76, Regestr Krzywd y Szkod poczynionionych przez Ich Mościów 
że kozakom „przed tym w Woiewodztwie Krakowskim płacono”. „Liqvidatia" mówi natomiast o zapłacie dragonom innych ćwierci niż 2 trwające łącznie od 1 października 1649 r. do 1 marca 1650 r. (te 2 uregulowane wedle „Zapłaty”, k. 40v-41) w województwie krakowskim. Należy zatem obie te chorągwie uznać za oddziały państwowe, a nie prywatne.

Ogółem w pułku Stanisława Lanckorońskiego, kaszt. kamienieckiego było 30 chorągwi w sile 2861 koni:

Husaria: 3 chorągwie,

1. królewska, por. Konstanty Kłobukowski ${ }^{47}$

376 koni

2. Stanisława Lanckorońskiego, kaszt. kamienieckiego, por. Jan Rzeczycki ${ }^{48}$

172 konie $(200) \mathrm{k}^{\star \wedge}$

3. Samuela Kalinowskiego, oboźnego koronnego, por. Sokolnicki

Rajtaria: 2 chorągwie,

1. Tobiasza Minora (-), por. Dębicki

2. Mikołaja Korfa, starosty kokenhauskiego Kozacy: 15 chorągwi,

88 koni $(100) \mathrm{k}^{* \wedge}$

116 koni $(120) \mathrm{k}^{*} \wedge$

187 koni

87 koni $(100) \mathrm{s}^{\wedge}$

100 koni (100), $\mathrm{s}^{\star \wedge}$

1312 koni

1. Stanisława Lanckorońskiego, kaszt. kamienieckiego, rtm. Hieronim Lanckoroński, por. Sobieszczański 69 koni, p

2. Stanisława Lanckorońskiego, kaszt. kamienieckiego 80 osób ${ }^{49}, \mathrm{p}$

3. Adama Kisiela, woj. kijowskiego (-) 109 koni, p

Panów Żołnierzów Niży opisanych wiernie y sprawiedliwie nic nie przydając y owszem umnieyszaiąc spisany. W Mieście Sieradzicach 1648, 15-18; Relatio posita Cittonis ad Tribunal Regni ex parte Subditoru de Villa Kęmpa con Gosczynski Vice Rotmagistrum Palatus Cracoviens, Kraków, 1649 r., 158-161; Sancti Spiritus super Cohortem Gnalis Cracous posita Cittonis Relatio, Kraków, 1649 r., 238-240.

47 Radwański, Zbaraska Expeditia, C, wymienia błędnie dwie królewskie, choć nie można wykluczyć, że rota ta ze względu na liczebność dzieliła się podczas walki na dwa hufce. Stawała ona do boju pod chorągwią ,adamaszkową, turkusową, po jednej stronie krzyż wielki kawalerski przez wszystkie biały, po drugiej żółty, we środku żółtego krzyża Najświętsza Panna z Dzieciątkiem, [h] aftowana subscriptio sub tuo presidio [podpis pod twoją obronę]. Na wierzchu u krzyża tecum a pro te [z tobą i za ciebie], na drugiej stronie we środku białego krzyża [h]aftowan[i]e herbów królewskich atłasem a s[z]nurkami”, zob. „Regestr dworzan JKM. pocztów pod chorągiew benedykowaną, turkusową, adamaszkową, podwiedzionych w Warszawie, w Lublinie i pod Sokalem - na wyprawę berestecką 1651 r.," w Relacje wojenne, 344.

48 Tak podaje: AP w Gdańsku, RSZP, sygn. 300.29.133, Instructia Ich Mosciom Panom, b.m., b.d, 322. Według Kochowskiego porucznikiem tej roty był Myśliszewski. Wersję z Rzeczyckim potwierdzają: Джерела з історії Національно-визвольної війни украйнського народу 1648-1658 рр., t. 1, (1648-1649 pp), red. Jurij Mytsyk (Київ: Інститут української археографії та джерелознавства ім. М.С. Грушевського, 2012), 291: „Od j. m. pana Rzeczyckiego, porucznika chorągwi usarski j. m. pana kamienieckiego" (nagłówek listu, zapewne z Kupieli, prawdopodobnie pisany około połowy czerwca).

49 AGAD, ASW, dz. 86, nr 39, Zapłata Woyskom, 39v, podaje: „Na Różne Ludzie [...] Jako Kozaki, Tak y Puszkarze 12400 florenów za 5 ćwierci”, co dla 80 osób daje po 31 florenów za 
4. margrabiego Władysława Myszkowskiego, woj. bracławskiego (-), por. Mikołaj Czeski lub Trzebiński ${ }^{50}$

5. Aleksandra Zamoyskiego, strażnika koronnego, por. Stanisław Kobylański

6. Samuela Kalinowskiego, oboźnego kor., por. Liniewski

7. Jerzego Lubomirskiego, star. krakowskiego (-), por. Franciszek Goszczyński

99 koni $(100) \mathrm{k}^{\star \wedge}$

100 koni (100), $\mathrm{s}^{* \wedge}$

87 koni (100), k

100 koni,

8. Piotra Firleja, star. trembowelskiego (-), por. Trzecieski

9. Andrzeja Potockiego, star. halickiego (-), por. Podbielski

100 koni (100), s

10. Adama Kazanowskiego, chor. sandomierskiego $(-)^{51}$

11. Mikołaja Kisiela, chorążego nowogródzkiego ${ }^{52}$, por. Pakosz

12. Aleksandra Koniecpolskiego drugiego $0^{53}$

$89 \operatorname{koni}(100), \mathrm{s}^{\wedge}$

97 koni (100), $\mathrm{k}^{\wedge}$

96 koni (100), $\mathrm{k}^{\star \wedge}$

8 koni, $^{* \wedge}$

ćwierć, a więc żołd kozacki. Można zatem uznać tę grupę za chorągiew kozacką z nielicznymi raczej puszkarzami.

50 Według księgi grodzkiej lubelskiej za rok 1648 był to Czeski, zob. AP w Lublinie, Zespół 8, sygn. RMO 76, Księga grodzka lubelska za rok 1648, [Lublin], 727v-728, a wg „Liqvidatii” Trzebiński, zob. BUWr., Steinwehr II F 37 vol. 2, Akc. 1949, 440, Liqvidatia Woisk Rzptej na Commissiey Lubel(skiey) 1650, 431v-432. Nie jestem w tej chwili w stanie stwierdzić, kiedy nastąpiła zmiana porucznika, a nawet czy w czasie obrony Zbaraża był nim na pewno jeden $\mathrm{z}$ wymienionych.

51 Według BUWr., Steinwehr II F 37 vol. 2, Akc. 1949, 440, Liqvidatia Woisk Rzptej na Commissiey Lubel(skiey) 1650, 431v-432, rotmistrz był podkomorzym sandomierskim, najwidoczniej po oblężeniu otrzymał nominację na wyższy urząd.

52 Chorągiew tę zaciągnięto we Lwowie na imię rotmistrza Morowińskiego, zob. BUWr, Steinwehr II F 37 vol. 2, Akc. 1949, 440, Comput Woiska zaciągu Lwowskiego z podpisem JMP. Wdy Ruskiego do Skarbu posłany, Służba im zaczęta a die 1. Octobr. 1648, b.m., 317; dopiero po nim otrzymał ją Mikołaj Kisiel, zob. AGAD, ASW, dz. 86, nr 37, Comput Woyska QVarcianego z Ordinatiey Rzeczypospolitey, b.m., 49. Według „Liqvidatii” rotmistrz był starostą czerkaskim. BUWr., Steinwehr II F 37 vol. 2, Akc. 1949, 440, Liqvidatia Woisk Rzptej na Commissiey Lubel(skiey) 1650, 431v-432, podaje jednak już urzędy, jakie dowódcy pełnili po oblężeniu, wcześniejsze - czyli aktualne dla czasu walk zbaraskich - urzędy podaje „Zapłata”, często obok urzędów aktualnych dla czasu rozliczeń; zob. np. AGAD, ASW, dz. 86, nr 39, Zapłata Woyskom, 23, gdzie mamy „Andrzeia Firleia Kasztellana Bełskiego, a potym Woiewody Sendomirskiego [...] Stanisława z Brzezia Lanckorońskiego, Kaztellana Kamienieckiego, a teraz Woiewody Bracławskiego". Urząd Kisiela podany tamże na karcie 26v.

53 Radwański, Zbaraska Expeditia, Cv, podaje „Aleksandra drugiego zaś Koniecpolskiego”, co oznacza, że nie chodzi o najbardziej znanego Aleksandra Koniecpolskiego, chorążego koronnego, lecz o kogoś innego, zapewne rotmistrza powiatowego Aleksandra z Koniecpola Koniecpolskiego, który również w 1648 r. prowadził kozacką rotę powiatową województwa krakowskiego w sile 100 koni - zob. Akta sejmikowe województwa krakowskiego, t. 2, 
13. Adama Duszyńskiego

14. Benedykta Ujejskiego, por. Mikołaj Białt $(-)^{54}$

15. Aleksandra Wiązewicza, por. Gurowski Dragonia: 10 chorągwi,

1. regiment Mikołaja Korfa (gwardia królewska), 8 kompani

2. Jerzego Lubomirskiego, star. krakowskiego (-), kpt. Samuel Grotkowski

3. Pawła Stokowskiego

Według „Liqvidatii” byli w pułku jeszcze dragoni Cikowskiego opłacani przez województwo krakowskie, ale nie zostali uwzględnieni w "Zapłacie”, więc mogli to być ci, którzy jako dragoni Lubomirskiego zostali rozbici 15 sierpnia pod Zborowem, ${ }^{55}$ a do pułku mogli zostać przyłączeni już po oblężeniu.

Kochowski, jak wspomniałem, wymienił w tym pułku chorągwie husarskie Jerzego i Konstantego Lubomirskich, które wg „Liqvidatii” były u Firleja. Pozostałe przyporządkował jak wyżej. Chorągiew kozacką Myszkowskiego z kolei umieścił Kochowski u Firleja, uważając ją jednak za husarską. Ponadto wymienił 10 rotmistrzów kozackich: Zamojskiego, strażnika koronnego; Jerzego (powinno być Mikołaja) Kisiela, chorążego nowogrodzkiego; (Aleksandra) Koniecpolskiego, Meleszkę, (Adama) Duszyńskiego, (Benedykta) Ujejskiego, (Piotra) Falbowskiego, (Piotra) Rajeckiego, (Aleksandra) Wiąziewicza i Suchodolskiego, tego ostatniego w cztery znaki ordynacji ostrogskiej. Przy tym miał być (Mikołaj) „Korff” z niemiecką jazdą (rajtarią) i z 8 znakami dragońskimi oraz dwa regimenty piesze, pod dowództwem

wyd. Adam Przyboś (Kraków: Nakładem Polskiej Akademii Umiejętności, 1953), 149. Obaj Koniecpolscy byli spokrewnieni. Chorąży koronny był prawnukiem Stanisława, kasztelana sieradzkiego, a drugi prawnukiem brata stanisławowego Mikołaja, kasztelana rozpierskiego, zob. „Rodowód Domu Koniecpolskich,” w Pamiętniki o Koniecpolskich, wyd. Stanisław Przyłęcki (Lwów: Nakł. Leona Rzewuskiego, 1842), 161 i n. Autor rodowodu, Zygmunt Stefan Koniecpolski, ur. 1588 r., twierdził, że on sam był rotmistrzem chorągwi powiatowej woj. krakowskiego, o tej funkcji Aleksandra nie wspomina.

54 AGAD, ASW, dz. 86, nr 39, Zapłata Woyskom, 28v, informuje, że chorągiew ta dostała żołd „darowny” na 100 koni, ale w dalszym fragmencie (k. 54) donosi, że „towarzyszom dwom Jmci P. Piotra Falibowskiego iako P. Andrzeiowi Horodyskiemu y Waleryanowi Mieczkowskiemu, którzy pod chorągwią Je ${ }^{\circ} \mathrm{Mci}$ Pana Vieyskiego z pocztami in obsidione Żbaraza służyli tedy na pięć koni F 150 ogółem na koni komputuiąc zapłacono F 750". ЛНБВС, OR, f. 5, о. 1, RВZNiO, sygn. II 225, Z Obozu Lith. die 10 July 1649, 242, donosi, że jeszcze 10 lipca porucznik Białt znajdował się w obozie litewskim.

55 „Diariusz Ekspedycyjej Zborowskiej,” 186. Z pewnością błędne jest stwierdzenie redaktora tego diariusza na s. 215 (przyp. 37), jakoby rozbitą pod Zborowem chorągwią dowodził Samuel Grotkowski, gdyż kompania Grotkowskiego otrzymała 2 miesiące darowne (AGAD, ASW, dz. 86, nr 39, Zapłata Woyskom, 41), co oznacza, że z pewnością była pod Zbarażem. 
Krzysztofa Przyjemskiego, dowódcy artylerii. ${ }^{56} \mathrm{~W}$ istocie Meleszko był rotmistrzem w wojsku litewskim, ${ }^{57} \mathrm{z}$ roty Falibowskiego zostało tylko wspomnianych 5 koni i weszły one w skład chorągwi Ujejskiego, chorągiew Rajeckiego odeszła wcześniej do Kamieńca, oddziały ordynata ostrogskiego nie wzięły udziału w obronie - nie dostały bowiem żołdu darownego wg "Zapłaty”, a co więcej list spod Zbaraża z 7 lipca od Firleja do króla mówi: „Ludzie Xiążecia JeoMci Pana Wdy Sendomierskiego pod Constantynowem Z nami niebyli, y teraz ich nie masz" ${ }^{58}$ Wreszcie Krzysztof Przyjemski miał tylko jeden regiment i to w pułku Firleja. Pod Zbarażem wedle jednej relacji miało być dwóch Przyjemskich, jeden „artyleryjej magister, a drugi oberszter" ${ }^{59} \mathrm{~W}$ istocie Zygmunt Przyjemski nie zdążył nawet pod Zborów. ${ }^{60}$

W pułku Ostroroga, oprócz wymienionych w „Liqvidatii” pod pozycją „Woisko Żbaraskie” oddziałów, znalazły się mniejsze pułki prywatne Sieniawskiego i Koniecpolskiego, o czym przekonuje także jeden z diariuszy oblężenia. ${ }^{61}$ Dzięki pracy Kochowskiego można przypuszczać, że niewymieniona w „Liqvidatii” i „Zapłacie” chorągiew Jana Karola Potockiego, a także dragonia Henryka Denhofa wchodziły w skład pułku Ostroroga. ${ }^{62} \mathrm{O}$ obecności prywatnej chorągwi kozackiej Potockiego pod Zbarażem informuje dokument z 1653 r. $^{63}$ Regiment Denhofa nie walczył pod Zbarażem w pełnym składzie. Dostał bowiem „Donatywy względem oblężenia zbaraskiego na dragunuw tylko no $200 \mathrm{~F} 4400 " .{ }^{64} \mathrm{O}$ tym, że ci dragoni stanowili dwie

\footnotetext{
56 Annalium Poloniae, 116-117.

57 Theatrum Europeaum, t. 6, Theatri Europaei oder Historischer Deschreibung der denckwürdiger Geschichten vom Jahr Christi 1647 biß 1651 (Frankfurt am Main: Matthaei Merians Seel. Erben/Druckts Daniel Fievet, 1663), 824: „Eine squadron Melesconischer leichter Pferd. 100”.

58 ЛНБВС, OR, f. 5, о. 1, RВZNiO, rkps II 225, Copia Listu do JKM od P. Bełskiego, b.m., b.d., 238-238v; Ojczyste spominki, 2:56-57.
}

59 „Diariusz Ekspedycyjej Zborowskiej," 177.

60 „Komput ludzi pod Zborowem (1649),” w Relacje wojenne, 330, wymienia wśród spóźnionych pod Zborów oddziałów regiment Krzysztofa, jednak AGAD, ASW, dz. 86, nr 39, Zapłata Woyskom, 53, wylicza dwa miesiące „darowne” za Zbaraż właśnie dla Krzysztofa. To oznacza, że spóźnionym oddziałem był w istocie regiment Zygmunta, który jeszcze 7 sierpnia bawił w Wielkopolsce, organizując swój regiment: AP w Poznaniu, Akta miasta Kalisza, sygn. I 188, Regestr Perceptorum Ciuitatis Calissiensis, Anno Dni 1649, Rationes Distribvtorvum Iego Mości P. Zygmunta Przyiemskiego gdy przyjechał samo dwudziest, Kalisz, 7 VIII 1649 r., 11-12.

${ }_{61}$ BZNiO, MIO, CdAC, sygn. II 9538, Diariusz rzeczy w Woysku naszym a Decima octava Juny [1649], b.m., 4, (4 lipca) „Jegomość P. Podczaszy z Pułkiem swoim w którym y Voluntarii Ichmść to iest Jegomść P. Chorąży, IMP. Sieniawski, IMP. Starosta krastonstawski byly, przeniósł się".

\section{Annalium Poloniae, 118.}

63 „Konstytucye y uchwała seymu walnego koronnego dwuniedzielnego, w Brześciu Litewskim, R.P. 1653 dnia 24 marca odprawowanego," w Volumina legum, 4:184.

64 AGAD, ASW, dz. 86, nr 39, Zapłata Woyskom, 53v. 
kompanie, przekonuje Radwański, który widzi pod Zbarażem dwie kompanie dragońskie starosty sokalskiego, a więc nie Henryka, lecz Stanisława Denhofa. Nie jest to jednak żadna sprzeczność, gdyż po zniesieniu regimentu Henryka pod Korsuniem list przypowiedni na jego regiment otrzymał 13 czerwca 1648 r. w Warszawie od prymasa Macieja Łubieńskiego właśnie Stanisław. Skądinąd wiadomo, że ów zniesiony regiment liczył pięć kompanii po 100 koni. Jedna $\mathrm{z}$ kompanii regimentu wzięła udział w wyprawie piławieckiej, gdzie musiała zostać rozbita wraz z resztą wojska, a cztery pozostałe nie zdążyły na czas. ${ }^{65}$ Dwie z nich były pod Zbarażem, a pozostałe miały być zdaniem Radwańskiego przy królu pod Zborowem. ${ }^{66}$ Najprawdopodobniej te dwie kompanie Denhofa przed oblężeniem zostały odesłane lub uciekły z obozu w kierunku Brodów, gdyż kozak wysłany przez Jana Dzika z obozu tuż przed nadejściem wroga (a więc 10 lipca) do Zamościa na trasie do Brodów „Chorągiew dragańską potkał, i drugą dragońską, nie wiem czyję, która także ku Brodom uchodziła”. ${ }^{77}$ Warto dodać, że chorągiew Komorowskiego była wcześniej w pułku Firleja, gdyż brała udział w podjeździe Krzysztofa Przyjemskiego, który został przez kasztelana bełskiego wysłany na Zwiahel w czerwcu. ${ }^{68}$

Podsumowując, w skład pułku Mikołaja Ostroroga, podczaszego koronnego wchodziło 35 chorągwi w sile 3114 koni i osób:

Husaria: 6 chorągwi,

618 koni

1. Mikołaja Ostroroga, podczaszego koronnego, por. Frykacz

98 koni (100), $\mathrm{k}^{\star \wedge}$

2. Michała Aleksandra Lubomirskiego, koniuszego kor. (-), por. Daniel Puzowski

92 konie (100), $\mathrm{k}^{* \wedge}$

3. Ludwika Szczawińskiego, star. brzeskiego (-), por. Rembieski lub Chomentowski ${ }^{69}$

99 koni (100), $s^{\star \wedge}$

65 AP w Gdańsku, Bibliotheca Archivi (dalej: BA), sygn. 300 R, Ee 32, Przypowiedny list Jego Msci Panu Sigmuntowi Donhofowi, Staroscie Sokalskiemu od Jego Msci X Arcybiskupa dany, b.m, b.d., 269-270; AGAD, ASW, dz. 86, nr 39, Zapłata Woyskom, 11; ЛНБВС, OR, f. 5, o. 1, RBZNiO, rkps II 225, Diariusz Obozowy a 1ma Septembr' ad 12 eiusdem, b.m., 162v-163v; B. Czart, rkps 143, Chorągwie, które wziąwszy pieniądze, w Obozie nie były, b.m, 165-166.

66 Radwański, Zbaraska Expeditia, Cv.

67 „Z Lublina d. 14 Julij 1649 r.,” w Ojczyste spominki, 2:62-63.

68 ЛНБВС, OR, f. 5, о. 1, RBZNiO, sygn. II 225, Copia Listu JMP Bełskiego do JKMci pisanego z obozu z pod Zasławia, de data 19 Juny 1649, 229v-230.

69 Rembieski wg BUWr., Steinwehr II F 37 vol. 2, Akc. 1949, 440, Liqvidatia Woisk Rzptej na Commissiey Lubel(skiey) 1650, 431v-432, Chomentowski wg Kochowskiego - Annalium Poloniae, 118. Co prawda Kochowski często się mylił, ale „Liqvidatia” zapewne podaje porucznika aktualnego dla czasu rozliczeń i nie można wykluczyć, że miał on poprzednika, który np. poległ lub zmarł. 
4. Adama Hieronima Sieniawskiego, star. lwowskiego por. Aleksander Ludwik Niezabitowski

132 konie (100), $\mathrm{k}^{* \wedge}$

5. Marka Sobieskiego, star. krasnostawskiego, por. Uniszewski

93 konie (100), $\mathrm{s}^{\star \wedge}$

6. Aleksandra Koniecpolskiego, chor. koronnego, por. Wyżycki

Kozacy: 24 chorągwie,

1. Jana Sokoła, por. Detyniecki

2. Seweryna Kalińskiego

3. Piotra Ozgi, pisarza ziemskiego lwowskiego (-), por. Dłużniewski

4. Hieronima Zbroskiego, starosty przasnyskiego, por. Babski

5. Adriana Okunia

6. Aleksandra Łysakowskiego

7. Jana Kazimierza Ponętowskiego, por. Swosz lub Kobeliński ${ }^{71}$

104 konie (100), $\mathrm{k}^{\star}$ ok. $2133^{70}$ koni

96 koni (100), $\mathrm{k}^{\star \wedge}$

100 koni (100), $\mathrm{k}^{\star \wedge}$

87 koni (100), k

97 koni (100), $\mathrm{k}^{\star \wedge}$

70 koni $(100) \mathrm{s}^{\wedge}$

91 koni $(100) \mathrm{s}^{\wedge}$

8. Adama Hieronima Sieniawskiego, star. lwowskiego, por. Słupecki ${ }^{72}$

9. Mikołaja Zaćwilichowskiego, por. Wyżycki

10. Tomasza Strzałkowskiego (-)

81 koni, $^{*}$

11. Proskury, por. Kowalewski

12. Ratowskiego

13. Marka Gdeszyńskiego (-), por. Szumlański

119 koni (100), s

94 konie (100), $\mathrm{k}^{\star \wedge}$

95 koni (100), $\mathrm{s}^{\wedge}$

94 konie (100), $\mathrm{s}^{\wedge}$

100 koni $(100), s^{\star \wedge}$

14. Michała Aksaka, podstolego kijowskiego, por. Gabriel Aksak

15. Jana Aksaka, star. ostrskiego, por. Wojakowski

16. Jacka Wozuczyńskiego, łowczego bełskiego

17. Stefana Komorowskiego, por. Aleksander Sokół

18. Aleksandra Koniecpolskiego, chor. koronnego, rtm. Mikołaj Wrzeszcz

91 koni (100), $\mathrm{k}^{\wedge}$

100 koni (100), $\mathrm{s}^{* \wedge}$

96 koni (100), $s^{\star \wedge}$

86 koni (100)s

100 koni (100), $\mathrm{s}^{\star \wedge}$

104 konie, $\mathrm{p}$

19. Aleksandra Koniecpolskiego, chor. koronnego, rtm. Daniel Czaplicki vel Czapliński (-), ze 150 ok. 100 koni, p

70 Dla chorągwi Karola Potockiego przyjąłem 100 koni, a więc typową liczebność chorągwi, aczkolwiek liczby mogły się w rzeczywistości różnić.

71 Tego pierwszego porucznika podaje dokument wymieniający chorągiew Ponętowskiego w pobliżu Krakowa wśród prywatnych oddziałów księcia Jeremiego po bitwie piławieckiej - AN w Krakowie, AGK, Relationes, nr 75, Oblata Lrarum scu Attonis Ponętowskiemu Seruien, Koszyczki, 1648 r., 1097-1099; drugiego podaje BUWr., Steinwehr II F 37 vol. 2; Akc. 1949, 440, Liqvidatia Woisk Rzptej na Commissiey Lubel(skiey) 1650, 431v-432. Kiedy nastąpiła zmiana porucznika, nie udało mi się ustalić.

72 Nazwisko porucznika za: „Akta Anni 1649 pod Zbarażem Nowym,” 144. 
20. Aleksandra Koniecpolskiego, chor. kor., rtm. Jan Strzyżowski

21. Jana Karola Potockiego

22. Mikołaja Ostroroga, podczaszego koronnego

50 koni, $\mathrm{p}^{*}$

? koni, $\mathrm{p}^{*}$

22 konie, $\mathrm{p}$

23. Adama Hieronima Sieniawskiego, star. lwowskiego, rtm. Kaliski

65 koni, $\mathrm{p}$

24. Adama Hieronima Sieniawskiego, star. lwowskiego, rtm. Pawłowski

95 koni, $\mathrm{p}$

Wołosza: 2 chorągwie, 88 koni

1. Mikołaja Ostroroga, podczaszego koronnego 18 koni, $\mathrm{p}$

2. Adama Hieronima Sieniawskiego, star. lwowskiego, rtm. Hohoł

Dragonia: 3 kompanie, 275 koni i osób

1. regiment Henryka Denhofa, 2 kompanie

2. Adama Hieronima Sieniawskiego, kpt. Balfar

Kochowski w pułku wymienił jedynie cztery chorągwie husarskie: (Adama Hieronima) Sieniawskiego, (Marka) Sobieskiego, (Michała Aleksandra) Lubomirskiego, (Ludwika) Szczawińskiego, 600 ludzi prywatnych Sieniawskiego i Sobieskiego, siedem lekkich chorągwi: (Franciszka) Zbroskiego, (Jana Karola) Potockiego, (Jana) Sokoła, Jana i Gabriela Aksaków, (Stefana) Komorowskiego, (Jana Kazimierza) Poniatowskiego i inną lub inne niezidentyfikowanych osób, wreszcie siedem kompanii dragońskich (Henryka) Denhofa i trzy piechoty węgierskiej. Jak widać, zamiast Michała wymienił Gabriela Aksaka, który mógł być ewentualnie porucznikiem tej chorągwi.

Wobec powyższych ustaleń nie ma miejsca na osobny pułk chorążego koronnego. Warto tu dodać, że liczba ok. 254 koni w oddziałach prywatnych Koniecpolskiego ma potwierdzenie $\mathrm{w}$ jednym $\mathrm{z}$ diariuszy, który informuje, że 13 lipca „JMP. Choraży Koronny przed choragwią Krolewska zagrzewaiąc serca Towarzyskie skoczył w ogień taki, że go nic a nic w ogniu nieprziiacielskim nie widać było, tylko że dextera Domini była cum eo, sparszy nieprziiaciela ta ch[o]rągwią y znakiem swoięm pod ktoręm było z pułtrzeciasta [250] koni illesus powrocił".73 Ów znak własny to z pewnością jego żołnierze prywatni. Co do chorągwi królewskiej - zapewne chodzi tu o jego własną chorągiew husarską będącą na żołdzie państwowym, a więc królewską. Ewentualnie, co wydaje się mniej prawdopodobne, chodzi tu o chorągiew zaciężną samego króla. Warto też wskazać chorągwie kwarciane, którymi na swoim odcinku dowodził Koniecpolski. O tym, że takie były, przekonuje Radwański. ${ }^{74}$ Pięć wymienia cytowany wyżej diariusz:

73 Biblioteka Jagiellońska (dalej: BJ), rkps 5, Dyariusz Żbaraskie ${ }^{\circ}$ Oblezenia 1649, b.m., b.d., 861.

74 Radwański, Zbaraska Expeditia, B4v. 
(Mikołaja) Zaćwilichowskiego, (Seweryna) Kalińskiego, Proskury, Ratowskiego i (Tomasza) Strzałkowskiego. Radwański podał w swoim spisie Jana Broniowskiego zamiast Ratowskiego. ${ }^{75}$

Kochowski pomija Proskurę, a oprócz pozostałych ww. wylicza jeszcze Jelca, Dzika, Cetnera i Golińskiego. Dzik, jak zobaczymy dalej, był porucznikiem husarskim u Jana Zamoyskiego, Jelec miał swoją chorągiew pod Zborowem, Cetner zapewne także, gdyż dostał tylko jedną ćwierć żołdową od 1 lipca i żadnych „darownych”, ${ }^{76}$ a rotmistrza Golińskiego nie znajdujemy w tym czasie. Warto zauważyć, że chorągwie Mikołaja Zaćwilichowskiego, Tomasza Strzałkowskiego i Jana Broniowskiego wymienione są jako prywatne oddziały chorążego koronnego w pobliżu Krakowa już po koronacji. ${ }^{77}$ Kaliński należał do pułku Koniecpolskiego w czasie wyprawy piławieckiej. ${ }^{78}$ Jedynie co do Proskury nie mam pewności, czy dowodził przed przyjęciem służby królewskiej chorągwią prywatną chorążego koronnego. Zdaniem Kochowskiego miała być w tym pułku jeszcze chorągiew Koniecpolskiego pod Wyżyckim, samego „Koniecpolskiego rycerstwa 300” (gdy faktycznie było tylko 250 kozaków), tegoż 400 dragonów i 2 węgierskie piesze chorągwie. Co ciekawe, cztery kompanie dragońskie i dwie piesze odnajdujemy w pułku wojewody ruskiego Jeremiego Michała Korybuta księcia Wiśniowieckiego. Wiemy również, że Kochowski sądził błędnie, że Koniecpolski przybył pod Zbaraż wraz z Wiśniowieckim i co więcej w czasie walk 10 lipca dwie chorągwie piesze widział tenże Kochowski w taborku książęcym. ${ }^{79}$ Wygląda zatem na to, że piechotę i dragonów księcia Jeremiego wziął za prywatnych ludzi Koniecpolskiego.

Omawiając skład pułku wojewody ruskiego, należy koniecznie poznać przebieg jego koncentracji przedstawiony w poemacie Jana Białobłockiego. Otóż książę Jeremi stał w Białym Kamieniu, gdy przed porankiem dnia św. Piotra (29 czerwca) doszła go wieść o panicznym odwrocie armii koronnej spod Konstantynowa. Wiśniowiecki miał w tym czasie 200 ludzi. Część z nich posłał przodem, a sam z resztą ruszył w południe tego

75 Ibid., Cv. Chorągiew Ratowskiego wymienia w walkach 10 lipca pod obozem: BJ, rkps 5, Dyariusz Żbaraskie ${ }^{\circ}$ Oblezenia 1649, b.m., b.d., 861.

76 AGAD, ASW, dz. 86, nr 39, Zapłata Woyskom, 35.

77 AN w Krakowie, AGK, Relationes, nr 76, Regestr szkód które Żołnierze poczynili w Miasteczku Szczekocinach, Kraków, 1649 r., 150-152; Relatio posita Cittonis ad Tribunal ex parte eo rund Opidanoru Sczekocinen Sup Vexilliferu Regni, Kraków, 1649 r., 196-198.

78 „List chorążego bracławskiego Jana Dzika 10 lipca 1648 r. z Szarogrodu do pana Jerzego Szornela, administratora i podskarbiego starosty kałuskiego (Jana Zamoyskiego)," w Документы об освободительной войне украинского народа. 1648-1654 г2. (Киев: Наукова думка, 1965), 73-74; „Pęcławski Cześnik Czerski do Kazanowskiego Marszałka Nadwornego Koronnego, z pod Konstantynowa 18 Września 1648," w Księga Pamiętnicza, 195.

79 Annalium Poloniae, 115, 118-119. 
dnia, docierając do Załoziec. 30 czerwca dotarł do Wiśniowca, wstępując po drodze do Andrzejowa, gdzie właściciel miejsca książę Michał Czartoryski „przyobiecał się chętnie w Kompanią [...] z swą Kawaleryą [...] Było do dwóch set człeka porządnego do boiu/ prawie Żołnierza dobrego". ${ }^{80}$ Oddział ten jednak nie dołączył tego dnia do Wiśniowieckiego, jak chce autor jedynej wartościowej biografii księcia Wiśniowieckiego - Władysław Tomkiewicz. ${ }^{81}$ Zrobił to dopiero później. W każdym razie po dotarciu do Wiśniowca książę rozpisał zaproszenia dla swoich oddziałów, w których miał wokół Wiśniowca „Pod tysiąc człeka przednie wybornego”. Te ruszyły na wezwanie. Oprócz nich także ludzie z Andrzejowa. Jeszcze w Wiśniowcu, najprawdopodobniej 1 lipca, wzmocnili pułk książęta Dymitr i Konstanty Wiśniowieccy (po opisie ich przyjścia Białobłocki informuje o porannym nabożeństwie w święto Nawiedzenia Najświętszej Maryi Panny, które przypada 2 lipca), którzy „W tysiącu niemal ludzi wszytkich przyszli/ Z Stryiem chcąc trzymać ze Zbaraża wyszli". ${ }^{82}$ Skądinąd wiadomo jeszcze o obecności w pułku książęcym oddziałów starosty kałuskiego Jana Zamoyskiego dowodzonych przez Jana Dzika. ${ }^{83}$ Wziąwszy pod uwagę, że Dymitr Wiśniowiecki miał tylko 525 ludzi, musiał zatem przyprowadzić jeszcze oddziały Zamoyskiego (482 konie i osoby) i działającą najprawdopodobniej razem z nimi chorągiew rajtarską/arkebuzerską Stanisława Kuleszy (91 koni). ${ }^{84} \mathrm{Ra}-$ zem wychodziłoby 1098 ludzi, a więc ponad tysiąc. Najprawdopodobniej zatem jedna z chorągwi - czy to Zamoyskiego, czy Dymitra Wiśniowieckiego - znajdowała się wcześniej pod Wiśniowcem i dołączyła do pułku księcia Jeremiego przed resztą oddziałów. Musiałaby być to jedna z większych chorągwi, by wszystko się zgadzało. Wziąwszy pod uwagę, że Wiśniowiecki miał jedynie 1031 koni i osób, wydaje się to jeszcze bardziej prawdopodobne. Jak bowiem wspomniałem, według Białobłockiego miał on - ruszając

80 Klar męstwa Na Obiaśnienie Pochodni. W dalsza droge ku nieugasłey Sławie Iaśnie Oświeconego Xiążęcia I. Mći, Ieremia Michała Korybvta na Wiśniowcu, y Łubniach Wisniowieckiego, Woiewody Rvskiego, Kaniowskiego, \& c. Starosty. Az do wyprawy woienney pod Zborow Samego Naiaśnieyszego Monarchy Krola Iego Mosci Jana Kazimierza nam szczęśliwie panującego. We czterech także Częściach wydany przez tegoż Authora, w Miesiącu Wrześniu. Roku Pańskiego 1649 (Kraków: Drukarnia Franciszka Cezarego I. K. M. Typogr., 1649), A4-Bv.

81 Władysław Tomkiewicz, Jeremi Wiśniowiecki (1612-1651) (Warszawa: Nakładem Towarzystwa Naukowego Warszawskiego, 1933), 312.

82 Klar męstwa, B-B3.

83 „Z Lublina d. 14 Julij 1649 r.," 62-63; Annalium Poloniae, 118.

${ }^{84}$ Katafalk Rycerski, 139. Autor relacji podaje, że w pułku Zamoyskiego „dragan ochotny pod sprawy twą Kulesso ogień miece lotny”. Co prawda Kulesza miał rajtarów, ale nie przeszkadzało to przecież, by dowodził jeszcze dragonami Zamoyskiego, jeśli faktycznie dołączył do jego ludzi. Radwański, Zbaraska Expeditia, C2, widzi jakąś rajtarię w oddziałach prywatnych. Jedyną kompanią rajtarską, której nie wymienił, jest ta chorągiew. 
z Białego Kamienia - 200 ludzi, których część poszła przodem, a gdy już dotarł, zastał na miejscu (zapewne razem $\mathrm{z}$ tymi idącymi przed nim) jeszcze blisko 1000.

Dopiero 2 lipca do Hniezdycznej (12 km na płd. zach. od Wiśniowca) przyszła chorągiew Czartoryskiego, a 3 lipca miała wejść do obozu książęcego, ${ }^{85}$ który tego dnia stanął już pod Siemkowcami/Szymkowcami. ${ }^{86}$

9 lipca pułk książęcy dotarł do Zbaraża. Na ten temat Kozak wysłany z obozu przez Jana Dzika donosił, że „Xiążę Wiśniowiecki wszedł w trzy tysiące do obozu, za którym i P. Dzik wszedł w siedm chorągwi P. Starosty kałuskiego" ${ }^{87}$ Problem w tym, że tych siedem chorągwi Zamoyskiego nie sposób wskazać. Widocznie zatem pod komendę Dzika oddano nie tylko rajtarów Kuleszy, ale i chorągiew Czartoryskiego.

Zestawienie $\mathrm{z}$ liczebnością oddziałów wymienionych wyżej panów sporządziłem na podstawie "Zapłaty”. Pomocna okazała się także „Liqvidatia”. Pojawiło się przy tym parę rozbieżności. O jednej już wspomniałem wyżej, przed omówieniem poszczególnych pułków. Oprócz tego w „Zapłacie” chorągiew Krzysztofa Stapkowskiego została zaliczona do tatarskich, a w „Liqvidatii” do wołoskich. Sprawę rozstrzyga jeden z diariuszy, który opisuje, jak 3 lipca wysłany na podjazd spod Zbaraża Hulewicz pod Ożochowcami „zichawszy się z Podiazdem Wołoszy y Tatarów Xiążęcia Woiewody Ruskiego mniemaiąc isz na kozaki y Tatary napadly rzeczy nie zrozumiawszy uciekly samego Hulewicza w kilkunastu koni zostawiwszy”. ${ }^{88}$ Omyłka w „Zapłacie" nie dziwi, gdyż zarówno oddziały wołoskie, jak i tatarskie zostały przy rozliczeniu żołdu potraktowane identycznie, tzn. dostały same ćwierci żołdu zasłużonego, ale nie dostały ćwierci „darownych”, w przeciwieństwie do właściwych chorągwi kozackich. Ciekawa jest także kwestia chorągwi pieszej Zamoyskiego, dowodzonej przez Różniatowskiego, w sile 120 ludzi. Jest ona wymieniona $\mathrm{w}$ „Liqvidatii”, ale pominięta $\mathrm{w}$ „Zapłacie”. O piechocie tej nie wspomina żadne inne znane mi źródło. Przyjmuję zatem, że oddziału tego prawdopodobnie w obozie nie było.

Podsumowując, pułk wojewody ruskiego Jeremiego Michała Korybuta księcia Wiśniowieckiego stanowiły 22 chorągwie liczące łącznie 2242 konie i osoby:

Husaria: 4 chorągwie, 390 koni

1. księcia Jeremiego Wiśniowieckiego,

rtm. Jan Baranowski, stolnik bracławski,

\footnotetext{
85 „Od pana Irzeo Jenicza, starszeo sługi kscia jeo mći Czartoryjskieo z Jendrzejówa d. 3 juły 1649," w Джерела, 1:276.

86 Klar męstwa, B3.

87 „Z Lublina d. 14 Julij 1649 r.” 63.

$88 \mathrm{BZNiO}, \mathrm{MIO}, \mathrm{CdAC}$, sygn. II 9538, Diariusz rzeczy w Woysku naszym a Decima octava Juny, b.m., [1649 r.], 4.
} 
por. Andrzej Rostkowski

2. księcia Jeremiego Wiśniowieckiego, rtm. Jan Grabie Wolski

3. Jana Zamoyskiego, star. kałuskiego (-), rtm. Jan Dzik, chor. bracławski

4. księcia Dymitra Wiśniowieckiego, rtm. Jan Libiszewski

Rajtaria: 1 chorągiew, 91 koni

1. Stanisława Kuleszy Kozacy: 9 chorągwi,

1. księcia Jeremiego Wiśniowieckiego, rtm. Andrzej Bestkowski

2. księcia Jeremiego Wiśniowieckiego, rtm. Stanisław Poniatowski

3. księcia Jeremiego Wiśniowieckiego, rtm Jan Bielecki

4. Jana Zamoyskiego, star. kałuskiego, rtm. Janicki

5. Jana Zamoyskiego, star. kałuskiego rtm. Marcin Oleśnicki

6. księcia Dymitra Wiśniowieckiego

7. księcia Dymitra Wiśniowieckiego, rtm. Andrzej Grocholski

8. księcia Dymitra Wiśniowieckiego, rtm. Stanisław Wolski

9. Michała Czartoryskiego, star. krzemienieckiego (-) 113 koni, p Wołosi:

1. księcia Jeremiego Wiśniowieckiego, rtm. Krzysztof Stapkowski Tatarzy:

1. księcia Jeremiego Wiśniowieckiego, rtm. Andrzej Mikołajewski

Dragonia: 4 kompanie, 320 osób

1. księcia Jeremiego Wiśniowieckiego, kpt. Hieronim Bostyka

2. Jana Zamoyskiego, star. kałuskiego (-), kpt. Bess

3. Jana Zamoyskiego, star. kałuskiego (-), kpt. Grzegorz Bachr

4. księcia Dymitra Wiśniowieckiego, kpt. Ormański Piechota polska: 2 kompanie, 200 osób

1. księcia Jeremiego Wiśniowieckiego, kpt. Rzeczkowski

2. księcia Dymitra Wiśniowieckiego
100 koni, $\mathrm{p}^{*}$

100 koni, $\mathrm{p}$

120 koni, $\mathrm{p}^{*}$

70 koni, $\mathrm{p}^{*}$

91 koni, 1026 koni

150 koni, $\mathrm{p}$

148 koni, $\mathrm{p}$

146 koni (100)s^

100 koni, $\mathrm{p}$

100 koni, $\mathrm{p}$

50 koni, $\mathrm{p}$

117 koni, $\mathrm{p}$

102 konie, $\mathrm{p}$

115 koni, $\mathrm{p}$

100 koni, $\mathrm{p}$

72 osoby, $\mathrm{p}$

80 osób, p

82 osoby, $\mathrm{p}$

86 osób, p

100 osób, p

100 osób, p 
Warto dodać, że Kochowski oprócz pozostałych husarzy tego pułku podaje tylko jedną chorągiew husarską samego księcia Jeremiego. Z „Zapłaty” wiemy jednak o podziale tej chorągwi na dwie. Nie wiadomo niestety, kiedy on nastąpił. Być może Kochowski nie wiedział o podzieleniu chorągwi na dwie. Po husarzach Kochowski pisze o „1000 rycerstwa” bez wyszczególnienia chorągwi. ${ }^{89} \mathrm{~W}$ chorągwiach kozackich widzimy dokładnie $1026 \mathrm{koni}$, co zgadza się z ustaleniami naszego kronikarza, trudno bowiem za „rycerstwo” uznać Wołochów i Tatarów (choć ten błąd zdarzył mi się w książce). ${ }^{90}$

Przejdźmy do piechoty wybranieckiej. Kochowski stwierdził trzy kompanie piesze typu węgierskiego w pułku Ostroroga. ${ }^{91}$ Znając brak precyzji Kochowskiego, nie można być jednak pewnym, że trzy spośród czterech chorągwi wybranieckich były właśnie w tym pułku. Poemat Radwańskiego wymienia jakichś pachołków łanowych - najpewniej wybrańców - na styku oddziałów Sieniawskiego i Sobieskiego z szykiem Wiśniowieckiego po korekcie wałów z 30 lipca, a dalej w tekście rotmistrzów łanowych Bobrownickiego, (Sebastiana) Kochanowskiego, Kopyślińskiego i (Daniela) Rasiowskiego, z których mieli być obecni jedynie dwaj pierwsi, gdy kompanie pozostałych mieli prowadzić słudzy rotmistrzów. Ponieważ Radwański wymienia też Bobrownickiego w przygródku, ${ }^{92}$ a z relacji samego Kochanowskiego wiadomo, że bronił miasta i to $\mathrm{w} 250$ pieszych, ${ }^{93}$ to wynika z tego, że kompania, która była w tym miejscu, należała do jednego $\mathrm{z}$ dwóch pozostałych, a druga walczyła wraz z Kochanowskim. Rasiowski to zapewne Daniel Raszewski, który z kwarty rawskiej za rok 1648 otrzymał 209 florenów na „Wybrańce Bełz[kie]”, za tenże rok Bobrownicki dostał 400 florenów na „Wybrańce Wielgopols[kie]”. ${ }^{4}$ Kochanowski otrzymał z kolei po 209 florenów rocznie za wyprowadzanie w pole wybrańców ruskich w latach 1648-1649. ${ }^{95}$ Wedle ustaleń Romana Rybarskiego w województwie ruskim było w 1650 r. 108 łanów wybranieckich, w bełskim 36, a w poznańskim i kaliskim razem 69 . W tych trzech chorągwiach

\footnotetext{
89 Annalium Poloniae, 118.

90 Rogowicz, Bitwa, 50.

91 Annalium Poloniae, 118.

92 Radwański, Zbaraska Expeditia, B3v-B4v, C2.

93 B. Czart., rkps 2482 III, Liber rerum variarum ... et antiquitatum, studio Casimiri Gardliński collectarum ab Anno 1660, (dalej: rkps 2482 III), Spisanie woiny kozackiey pod Żbarażem i z ordą przez pana Sebastiana Kochanowskiego cześnika lwowskiego, b.m., b.d., 156-157, 164. Kochanowski miał dołączyć do armii koronnej 23 czerwca pod Czołchańskim Kamieniem (nie zgadza się data lub miejsce, bo w tym czasie armia koronna była pod Hrycowem i Międzybożem, możliwy błąd w zapisie, lepiej pasowałby do miejsca 28 czerwca). Jego piechurów wspomagała „różna drużyna w mieście nazbierana”.
}

94 AGAD, ASK, dz. 86, nr 37, Distribvta Quarty Rawskiey An(n)i MDCXLVIII, b.m., 41.

95 AGAD, ASW, dz. 86, nr 39, Zapłata Woyskom, 18. 
powinno być zatem ok. 213 ludzi. Dodatkowa chorągiew, którą obok swojej dowodził Kochanowski, musiała liczyć ok. 142 ludzi, może nawet 150. Nie była to więc chorągiew Raszewskiego, która musiała się znaleźć właśnie na styku pułku Ostroroga z oddziałami/pułkiem Wiśniowieckiego. Mogła ona pochodzić z województwa mazowieckiego, które miało 151 łanów wybranieckich lub podlaskiego, które miało ich $179 .{ }^{96}$ Wybrańcy podlascy Jabłonowskiego byli jednak w pewnym momencie pod Toporowem wraz z armią królewską idącą na odsiecz, a zatem pod Zbaraż nie dotarli. ${ }^{97}$ Najprawdopodobniej zatem ostatni oddział piechoty wybranieckiej stanowili Mazurowie. W sumie powinno być ok. 355 wybrańców.

Siłę artylerii podał jej dowódca - kapitan armatny Sebastian Aders. Miała ona 5 oktaw i 10 działek regimentowych. ${ }^{98}$ Do tego dochodziła nieznana liczba dział na zamku zbaraskim i być może jakieś działa przyprowadzone przez pułk Wiśniowieckiego. Porucznikiem armatnym był Wojciech Radwan Radwański. ${ }^{99}$ Zdaniem Kochowskiego artylerią dowodził Krzysztof Przyjemski - w zasadzie nie można tego zupełnie wykluczyć, jednak jeśli tak było, to nie wynikało z jego funkcji, gdyż nie był on starszym nad armatą, jak chce Kochowski. Funkcję tę pełnił nieobecny Krzysztof Arciszewski, który wziął udział w wyprawie odsieczowej. ${ }^{100}$

Podsumowując i licząc po 100 koni lub osób dla oddziałów o nieznanej liczebności, otrzymujemy ok. 12824 konie i osoby w 134 chorągwiach: 8938 jazdy i 3886 pieszych i dragonów.

Jeśli zrobimy podsumowanie oddziałów państwowych (kwarcianych, suplementowych, powiatowych i wybranieckich), otrzymamy:

- 15 chorągwi husarskich w sile 1487 koni, ${ }^{101}$

- 5 chorągwi rajtarskich w sile 475 koni,

- 10 chorągwi arkebuzerskich w sile 1021 koni,

- 35 chorągwi kozackich w sile 3266 koni,

- 22 kompanie dragońskie w sile 2236 koni,

- 6 pieszych kompanii niemieckich w sile 600 osób,

- 1 pieszą kompanię polską w sile 100 osób,

96 Roman Rybarski, Skarb i pieniq̨dz za Jana Kazimierza, Michała Korybuta i Jana III (Warszawa: Towarzystwo Naukowe Warszawskie, 1939), 108.

97 B. Czart, rkps 144, Komput woyska zgromadzonego pod Toporowem do Króla Jmci, [Toporów], b.d., 715 .

98 Księga Pamiętnicza, 409-410.

99 Zob. Radwański, Zbaraska Expeditia, C2v, gdzie Radwański podaje swoją funkcję.

100 Annalium Poloniae, 116; Konstanty Górski, Historya artyleryi polskiej (Warszawa: Wende E. i Spółka, 1902), 113-114, 120-121.

101 Wimmer, Wojsko polskie, 63, podał 14 o sile 1439 koni, ale to dlatego, że husarską kompanię Sierakowskiego (48 koni) zaliczył do arkebuzerskich. 
- 4 piesze kompanie wybranieckie/łanowe w sile ok. 355 osób razem ok. 9540 koni i osób w 98 chorągwiach.

Jeśli podsumujemy siłę pocztów panięcych, otrzymamy:

- 4 chorągwie husarskie i suplement państwowej w sile $422 \mathrm{koni},{ }^{102}$

- 25 chorągwi kozackich i suplement państwowej w sile ok. 2267 koni,

- 5 kompanii dragońskich w sile 395 koni i osób,

- 2 kompanie piesze w sile 200 osób, razem ok. 3284 koni i osób w 36 chorągwiach i 2 suplementach.

Podsumowując dla konkretnych formacji, otrzymamy:

- 19 chorągwi husarskich w sile 1909 koni,

- 5 chorągwi rajtarskich w sile 475 koni,

- 10 chorągwi arkebuzerskich w sile 1021 koni,

- 60 chorągwi kozackich w sile 5533 koni,

- 27 kompanii dragońskich w sile 2631 koni,

- 13 różnych kompanii pieszych w sile 1255 osób.

Oprócz powyższych oddziałów Radwański wymienił pod Zbarażem jeszcze trzy inne chorągwie kozackie: wojewodzica łęczyckiego, Niezabitowskiego, Łychowskiego. ${ }^{103}$

Chorągiew niejakiego Jana Niezabitowskiego występuje tylko w jednej $\mathrm{z}$ wersji komputu wojska suplementowego, ${ }^{104} \mathrm{w}$ innych źródłach jej nie ma. Podejrzewałem, że to ta, którą dowodził Jan Ponętowski - uwzględniony $\mathrm{w}$ „Zapłacie”, a nieobecny w komputach. $\mathrm{W}$ istocie jednak chorągiew Jana Kazimierza Ponętowskiego przed wejściem do służby królewskiej należała do prywatnych oddziałów księcia Jeremiego Wiśniowieckiego. ${ }^{105} \mathrm{~W}$ tej chwili bardziej prawdopodobne wydaje się, że Radwański się mylił, niż że jakaś dodatkowa chorągiew brała udział $\mathrm{w}$ walkach.

Wojewodzicem łęczyckim był Zygmunt Przerębski. Jego chorągiew dostała żołd na 100 koni za kwartał poprzedzający obronę Zbaraża. ${ }^{106}$ Pod Zbarażem jednak nie była, a jej resztki w sile 30 koni znalazły się przed wyprawą

\footnotetext{
102 Ibid. Wimmer podał 5 o sile 422 koni, ale jak wspomniałem, dodatkowi husarze Sieniawskiego wchodzili w skład jego chorągwi kwarcianej.

103 Radwański, Zbaraska Expeditia, C-Cv. Inną wersję przy chorągwi Łychowskiego podaje Kochanowski: B. Czart., rkps 2482 III, Spisanie woiny kozackiey pod Żbarażem i z ordą przez pana Sebastiana Kochanowskiego cześnika lwowskiego, b.m., b.d., 161: „Za tym Łychowskie /Była z nami, y wyszła”. Według Radwańskiego „Weszła”.

104 B. Czart., rkps 144, Comput woyska suplementowego, b.m., b.d., 795.

105 AN w Krakowie, AGK, Relationes, nr 75, Oblata Lrarum scu Attonis Ponętowskiemu Seruien, Koszyczki, 1648 r., 1097-1099.

106 AGAD, ASW, dz. 86, nr 39, Zapłata Woyskom, 27. Konstitvcie seymv, 23, informują o zapłacie 3058 zł dla tej chorągwi przez ziemię wieluńską.
} 
zborowską pod Brodami. ${ }^{107}$ "Liqvidatia” wskazuje, że Przerębski był sądzony, bo pieniądze „co Ćwierć biorąc, Stacie wyciągaiąć w Obozie [zbaraskim M.R.] nie był, o Kozaków, - 100".

Łychowskim był Jan, podstoli, a później chorąży bełski. „Liqvidatia” podaje w pułku podczaszego koronnego, że „Chorążego Bełskiego Sądzono, że odiachał z Obozu, gdy Nieprzyjaciel następował”. Chorągiew Łychowskiego miała dostać wg tegoż dokumentu 2 ćwierci żołdowe w województwie, a pozostałe miała odsądzone. Łychowski miał później zwrócić do skarbu pieniądze za jedną ćwierć na 100 koni. ${ }^{108}$ Wedle dalszej części „Liqvidatii” chorągiew ta w sile 100 koni była pod Zborowem.

Na końcu należy też wyszczególnić dwie chorągwie kozackie, które dołączyły wkrótce przed walkami. Jedna, dowodzona przez Piotra Rajeckiego, została odesłana ze Zbaraża do Kamieńca, za co dostała ćwierć darowną: „A za Darowną Jednę Cwierć respectu tego ze z rozkazania Ich Mściow Panow Wodzow z pod Żbaraza wysłana była do Kamieńca Podolskiego Na Koni № 100. Przyznanych dano Fl[orenów] 3100". Chorągiew ta została odesłana zapewne nie wcześniej niż 30 czerwca, bo „Zapłata” mówi o jego odesłaniu ze Zbaraża, co byłoby niemożliwe przed tą datą. Jedną ćwierć darowną „zbaraską” na 100 koni dostała także chorągiew kozacka starosty kamienieckiego Piotra Potockiego. To oznacza, że także była podczas walk zbaraskich w Kamieńcu. ${ }^{109} \mathrm{~W}$ przypadku drugiej chorągwi - Piotra Falibowskiego - stwierdziłem swego czasu, że „wyjechał ze swoją rotą późnym wieczorem, po walkach 10 lipca i już po przyjściu Chmielnickiego z chanem. Dwóch towarzyszy z jego roty przegapiło wyjazd i zostało na miejscu w 5 koni". ${ }^{110}$ Tezę tę oparłem na źródle mówiącym, że „P. Chwalibowski Rotmistrz Pana Starosty Kałuskiego, który dziś tydzień wyjechał z obozu naszego, dziś przyjechawszy w nocy, powieda, że się Chmiel znowu wrócił". ${ }^{11} \mathrm{O}$ odejściu Falibowskiego wspomniał również Radwański:

107 „Komput wojska, które ma być w obozie z Królem w Czerwcu lub Lipcu 1649,” w Księga Pamiętnicza, 428, podaje pod pozycją "Ludzie w Brodach będący” m.in. „Pana Wojewodzica Łęczyckiego 30". Tych 30 ludzi to mogły być resztki chorągwi, która uciekła z wojska zbaraskiego.

108 AGAD, ASW, dz. 86, nr 39, Zapłata Woyskom, 30v, donosi, że: „Je Mści Pana Lychowskiego Za Assignatią Skarbową z ziemi Sanockiey zapłacono ktora summa per Decretum do Skarbu od tego Pana Łychowskiego ma bycz powrocona Fl 3100".

109 Ibid., 25v, 36; AP w Gdańsku, RSZP, sygn. 300.29.133, Script ad Archivum na Seymie 1649 d(ie) 22 Novembris od Stanów Koronnych podany, Warszawa, 443-444v: „Uważaiąc dzielność y odwagę pułku Kamienieckiego sześci set ludzi, którzy byli pod Regimentem Wielmożnego Stanisława z Brzezia Lanskorońskiego Wdy Bracławskiego, Regimentarza Woysk naszych, iednę darowną Ćwierć onym pozwalamy”.

110 Rogowicz, Bitwa, 53.

111 „Wiadomości ze Zbaraża oblężonego, Zbaraż 17 Lipca 1649,” w Księga Pamiętnicza, 417. Podane miejsce powstania dokumentu z pewnością błędne. 
„Był Chwalbowski/ods[z]edł nas”. ${ }^{12}$ Rzecz jednak w tym, że Falibowski nie był rotmistrzem starosty kałuskiego, a królewskim, natomiast „Pan Chwalibowski” był to „Towarzysz z pod Chorągwi Pana Starosty Kałuskiego, wyiachał z Obozu wyprawiony od P. Bełskiego $10 \operatorname{Pr}\left[\right.$ ese]ntis", czyli 10 lipca. ${ }^{113}$ Chorągiew Falibowskiego natomiast odeszła $\mathrm{z}$ wojska $\mathrm{w}$ nieokreślonym jak dotąd momencie najprawdopodobniej przed 2 lipca, gdyż w liście Ostroroga z 3 lipca czytamy, że „nie tylko pacholikowie ale i Towarzystwo odjeżdżają od chorągwi, tak że pod drugiemi [niektórymi] nie masz jedno połowica i mniej. A wczora kiedy kazano jednej na podjazd, nie poszła jedno samopięta. - Między cudzoziemskimi ludźmi summa diminutio [podobne ubytki] także". ${ }^{114}$ Widocznie to już wtedy $\mathrm{z}$ tej chorągwi zostało pod Zbarażem zaledwie wspomniane wcześniej 5 koni, które dołączono następnie do chorągwi Ujejskiego.

Niestety, ustalony wyżej skład wojska nie jest do końca miarodajny, gdyż w armii polskiej w tym czasie nie było zróżnicowanych stawek żołdu ze względu na stanowisko, a jedynie na formację, w jakiej się służyło. Przyjął się zatem zwyczaj, że oficerowie podawali stan wyższy niż rzeczywisty, by otrzymać większe wynagrodzenie. Liczba żołnierzy była w związku z tym niższa od liczby, za którą płacono. Udział procentowy tzw. ślepych stawek żołdu w różnych okresach wahał się od 16,7 do $30 \%$. I tak w XVI w. w piechocie jeszcze za czasów hetmaństwa Jana Tarnowskiego i aż do czasów Stefana Batorego wynosił ok. 20\%. ${ }^{115}$ Już z czasów Batorego, z roku 1577, pochodzi popis roty pieszej, z którego wynika, że ślepe porcje stanowiły wtedy dokładnie 20\%. ${ }^{116}$ Według Górskiego za czasów Batorego praktyka ślepych porcji została zarzucona, jednak przeczą temu źródła siedemnastowieczne, choć niestety wykazy z tego okresu nie pozwalają uchwycić udziału ślepych porcji. Możemy je jedynie wykazać, znajdując różnicę między liczbą wojska podawaną przez źródła narracyjne a wynikającą z wykazów zapłaconego żołdu. Dopiero pod koniec XVII i na początku XVIII w. znajdujemy źródła, które wyraźnie podają liczbę ślepych porcji. I tak, w $1671 \mathrm{r}$. Jan Sobieski, opisując stan wojska, twierdził, że „tym dwunastu tysięcy wytrąciwszy ślepe poczty, a z cudzoziemskiego woyska Officierskie płace, nie zostanie tedy plus minus nad dziesięć tysięcy woyska". ${ }^{117}$ Widzimy tu więc

\footnotetext{
112 Radwański, Zbaraska Expeditia, Cv.

113 B. Czart., rkps 144, Nowiny z Ukrainy de Dtta [sic!] 13 july, b.m., 373.

114 Ojczyste spominki, 2:54.

115 Górski, Historya piechoty polskiej (Kraków: Księgarnia Spółka Wydawnicza Polska, 1893), 19-21.
}

116 Źródła dziejowe, t. 20, Polska XVI wieku pod względem geograficzno-statystycznym, t. 9, Ziemie Ruskie. Ukraina (Kijów - Bracław). Dział 1-szy opisane przez Aleksandra Jabłonowskiego (Warszawa: Skład główny w Księgarni Gebethnera i Wolffa, 1894), 145-149.

117 Cyt. za: Radosław Sikora, Husaria pod Wiedniem 1683 (Warszawa: Wyd. Erica, 2012), 79. 
1/6 ślepych porcji. Następnie w 1703 r. hetman Hieronim Lubomirski twierdził, że „z tych bowiem ośmiu tysięcy kawalerji, które w kompucie mamy, wytrąciwszy poczty rotmistrzowskie, nuż tak wielu panów deputatów około wybierania hyberny i zasług zabawnych, do tego panów oboźnych, koniuszych, to do boju et ad operationes belli około dwóch tysięcy ubędzie koni. Toż rozumieć o regimentach ile na tak drobne części podzielonych, choćby i komplet były, to $\mathrm{z}$ dziesięciu tysięcy ledwieby się siedm tysięcy ludzi znalazło, wytrąciwszy oficerskie sztaby". ${ }^{118}$ Podobne przeliczniki można zastosować i dla lat 1648-1649: przykładowo pod Korsuniem 25-26 maja 1648 r. przy 5,5 tys. stawkach żołdu było 4 tys. żołnierzy, ${ }^{119}$ a 26-28 lipca $1648 \mathrm{r}$. przy niecałych 8 tys. pod Konstantynowem 6 tys. do boju. ${ }^{120}$ Wreszcie co do obrony Zbaraża Kochowski informował, że „liczba wojska rachowała się 12,000 tysięcy, ale ledwie do boju było 9 tysięcy". ${ }^{121}$ Stąd poznajemy nie tylko liczbę etatową, ale i faktyczną, a także odsetek ślepych porcji w tym czasie.

W przypadku walk zbaraskich nie możemy po prostu od wyliczonych 12824 odjąć $25 \%$ tej liczby na ślepe porcje, gdyż - jak wynika z dokumentów - żołd zapłacono na więcej stawek, niż się należało. Przykładowo wiadomo o braku pod Zbarażem kilkudziesięciu ludzi z regimentu Krzysztofa Przyjemskiego: chorążego Stanisława Jeleńskiego i porucznika Hieronima Wegiera, który był „Comenderowany z kilkadziesiąt człowieka” i do wojska już nie dołączył. ${ }^{122} \mathrm{~W}$ związku z tym charakterystyczne jest to, że liczba niemal 13 tys. żołnierzy jest rzadko spotykana w źródłach dotyczących walk zbaraskich - znalazłem ją w jednym zaledwie dokumencie, gdzie mamy informację, że „naszym dus[z]no ktorych więcej nad trzynastie tysięcy w obozie nie masz". ${ }^{123}$ Taki stan rzeczy spowodowany był nasilonymi dezercjami,

118 Kazimierz Piwarski, „Votum hetmana Hieronima Lubomirskiego na sejmie lubelskim w 1703 r., PHW 6, z. 1 (1933): 113-114. „Oboźnych, koniuszych” - wygląda z tego, że część trzymających zapasowe konie, a czasem i zwykłych ciurów obozowych towarzysze przy sporządzaniu rolli także przedstawiali jako pocztowych.

119 Rogowicz, „Skład sił polskich nad Żółtymi Wodami i pod Korsuniem w 1648 roku,” PHW 16 (67), nr 2 (252) (2015): 54, 57.

120 Rogowicz, „Bitwa pod Konstantynowem, 26-28 lipca 1648 roku,” PHW 18 (69), nr 2 (260) (2017): 21-22.

121 W oryginalnej łacińskiej wersji Annalium Poloniae, 118: „Certe numerus bellatorum ad novem Mill: vix extendi poterat, cum XII. Mill: in apparentiam censeretur: sueto militiae more, praegnantes Matriculas aerario obtrudere, raro apud sterilia signa militie, \& depascendis hybernis, quam condensandis Ordinibus frequentiore”. Luźny przekład za: Wespazjan Kochowski, Historya panowania Jana Kazimierza przez nieznajomego autora wydana z rękopisu przez Edwarda Raczyńskiego, t. 1 (Poznań: Walenty Stefański, 1840), 54.

122 AN w Krakowie, Księgi Grodzkie Bieckie, nr 183, Jelenski contra Wegier Prottur, b.m., b.d., 1737-1739.

123 ЛНБВС, OR, f. 5, o. 1, RBZNiO, sygn. II 189, Nowyni Ż ukrainy do [od] Xsiążęcia JM Czartoryskiego, b.m., 1649 r., 262. 
jakie miały miejsce przed przybyciem Wiśniowieckiego w pobliże obozu zbaraskiego. Późniejsze powroty uciekinierów nie zdołały wyrównać wszystkich ubytków. Jednak oficerowie i żołnierze wojsk zaciężnych dostali zapłatę tak, jakby oddziały były kompletne. Wyjątek dotyczy niektórych chorągwi - prawdopodobnie na podstawie popisu, który przeprowadzono już pod samym Zbarażem 6 lipca. ${ }^{124}$ Porównując stany chorągwi w poszczególnych ćwierciach 1649 r., możemy stwierdzić, że popis dotyczył zaledwie kilku-kilkunastu jednostek zaciężnych. ${ }^{125}$ Były to najprawdopodobniej husarskie: królewska, Stanisława Lanckorońskiego, Aleksandra Lubomirskiego, Konstantego Lubomirskiego ${ }^{126}$; kozackie: Samuela Kalinowskiego, Mikołaja Kazimierza Kossakowskiego, Zahariasza Czetwertyńskiego, Łukasza Hulewicza, Jacka Wozuczyńskiego; rajtarska Andrzeja Sierakowskiego pod Charlińskim; arkebuzerska Tobiasza Minora i dragońska Piotra Stokowskiego.

By ustalić, ile stawek żołdu należało się wojsku, musimy skorzystać z dodatkowych źródeł. Liczby podane przez Kochowskiego przytoczyłem wyżej. Natomiast wg Wojciecha Michałowskiego - żołnierza armii odsieczowej: „zmniejszywszy okopów ex consilio ipsius [za jego własną radą - chodzi o radę Wiśniowieckiego - M. R.], które niepodobna rzecz było bronić dla szczupłości wojska, gdzie jako constat [stwierdzono] nad dwanaście tysięcy więcej go nie było". ${ }^{127}$ Liczba ta była szeroko znana. Już wiele lat po bitwie podawali ją inni. Między innymi Jemiołowski zapisał, że: „Chmielnicki [...] przeciwko wojsku ledwie we dwanaście tysięcy natenczas zebranemu (bo drugie chorągwie jeszcze były nie przyszły) śmiele poszedł i gwałtownie napadłszy, nie gotowych i nieco żywność przysposobionych pod Zbarażem osaczył”. ${ }^{128}$ Podobnie podawał autor

124 Datę popisu podaje: BZNiO, MIO, CdAC, sygn. II 9538, Diariusz rzeczy w Woysku naszym a Decima octava Juny [1649], b.m., 5. Pamiętniki Albrychta Stanisława X. Radziwiłła kanclerza w. litewskiego, wyd. Edward Raczyński (Poznań: Bracia Szerk, 1839), 396, pod dniem 9 XII 1649 r. informują: „Proponowana też była kwestya, o weryfikacye liczby wojska, bo komissya rawska za nieważną jest osądzona, gdyż tym żołnierzom i chorągwiom jest zapłacono, którzy ani pod Zbarażem, ani z królem pod Zborowem nie byli; a do tego nie zupełne były chorągwie, osobliwie cudzoziemskie, przeto niech przysięgną, jeźli był komplet ich”. Z ilości, za jaką w końcu zapłacono na komisji lubelskiej, wynika, że jednak do weryfikacji liczby wojska nie doszło. Stąd mamy różnicę między właściwym stanem etatowym a tym, za który zapłacono.

125 Stany oddziałów w poszczególnych ćwierciach podaje AGAD, ASW, dz. 86, nr 39, Zapłata Woyskom; zob. też sporządzoną na ich podstawie tabelę z liczbami: Rogowicz, Bitwa, 155-158 (aneksy II i III).

126 Może to potwierdzać następujący ustęp: „A za Darownych Cwierci № 4 Tylko na Koni N ${ }^{\circ}$ 90 bo tym ktorzy nie byli praesentes in Obsidione zbaraza Darowizny nie przyznano, a na tych co byli Przychodziło y zapłacono Fl 14760", AGAD, ASW, dz. 86, nr 39, Zapłata Woyskom, 24.

127 „Diariusz Ekspedycyjej Zborowskiej,” 178.

128 Pamiętnik Mikołaja Jemiołowskiego, towarzysza lekkiej choragwi, ziemianina województwa bełzkiego, obejmujący dzieje Polski od roku 1648 do 1679 spółcześnie, porządkiem lat opowiedziane (Lwów: Drukarnia Zakładu Narodowego im. Ossolińskich, 1850), 12. 
jednego z poematów dotyczących tematu: „do boiu tylko dwanascie tysiąc[y] się rachowało". ${ }^{29}$

Liczebność wojska do boju była oczywiście mniejsza ze względu na ślepe porcje żołdu. Należy jej szukać w liczbach wyraźnie niższych niż 12 tys. Najniższą taką wartość - 8 tys. - znajdujemy w krótkiej zapisce nieznanego autora dotyczącej lat 1646-1655. ${ }^{130}$ Podobną wzmiankę odnajdujemy w wierszu z epoki: „ośm tysiący mało co więcej obozem Stało koronnych Synow obronnych". ${ }^{131}$

Kochowski, jak wspomniałem, rachował 9 tys. Tak samo stwierdzają relacje Viminy i Pastoriusa. ${ }^{132}$ Ten pierwszy podał jeszcze liczbę kompanii, ale mylnie, bo 106 .

List regimentarza Andrzeja Firleja z 7 lipca spod Zbaraża stwierdza: „Co strony Woyska WKMci że go nie było na ten czas nad sześć Tysięcy, y teraz WKMciPaMM podawam do wiadomosci, bo lubo według computu którym WKMci posłał miało go bydz nad dziesięć tysięcy, tedy Chorągwie tak kuse że ledwie sześć Tysięcy do bitwy wyłata. Ludzie Xiążecia JeoMci Pana Wdy Sendomierskiego pod Constantynowem $\mathrm{Z}$ nami nie byli, y teraz ich nie masz potym iusz dopiero ludzie JeoMci Pana Sieniawskiego przyszli, ludzie JeoMci Pana Wdy Ruskiego, JeoMci Pana Starosty Kałuskiego, takze Xiąząt młodych Wiśniowieckich przychodzą. ${ }^{133} \mathrm{O}$ tym kompucie dowiadujemy się także z listu króla do Firleja pisanego zapewne na początku lipca. Król miał w nim pretensje o to, że Firlej pismem z 28 czerwca spod Czołchańskiego Kamienia donosił mu o liczebności wojska na poziomie 6 tys., gdy tymczasem wg przysłanego wcześniej komputu miało być 10 tys. Jak pisał król: „to nam musi bydz w podziwieniu, że nam tylko o sześciu tysięcy woiska wiern. tw. piszesz, podobno zapomniałeś wiern. tw. computa swego, do nas posłanego, z którego pokasuie się, że około dziesięci tysięcy woiska miało się na on czas znajdować, przy obu wiern. ww., oprócz inszych chorągwi,

129 Biblioteka PAU/PAN w Krakowie, rkps 1275, Kronika rymowana wypadków politycznych w Polsce od r. 1648-1672, b.m., b.d., 12v.

130 Документы, 9.

131 „Lament nad ojczyzną, w ktorym się krotko pokazuje, co się z Koroną Polską od śmierci Władysława IV krola działo przez siedm lat znaczny klimakterik od roku 1648 aż do roku 1656," ш Джерела, 1:431.

132 Alberto Vimina, Historia delle guerre civili di Polonia divisa in cinque libri progressi dell'armi Moskowite contro Polacchi (Venezia: Appresso Gio: Pietro Pinelli, 1671), 143: „Consisteua tutto l'Essercito Polacco in cento e sei Compagnie, ma non affatto piene, di maniera, cha pena compiuano il numero di noue milla combattenti". Joachim Pastorius, Bellum scythico cosacicum, seu de coniuratione Tartarorum, Cosacorum et plebis Russicae contra Regnum Poloniae (Dantisci: Sumptibus Georgy Fortisci S.R.M.Bibliopolae, 1652), 34.

133 ЛНБВС, OR, f. 5, о. 1, RBZNiO, rkps II 225, Copia Listu do JKM od P. Bełskiego, b.m., b.d., 238-238v; Ojczyste spominki, 2:56-57. 
kóre interim do wiern. tw. poszły, nie wspomianiąc ludu wielmożnego woiewody sendomirskiego y innych, którzy z ochoty swoiey kosztem własnym zaciągnione pułki swoie tamże do wiern. tw. Stawili". ${ }^{134}$

Warto się zastanowić, jakie oddziały stanowiły podstawę dla tego komputu. Zacznijmy od tego, że w takich komputach podawano zwykle okrągłe liczby - podobnie jak w komputach uchwalanych na sejmie. Jeśli podsumujemy siłę wszystkich oddziałów królewskich w pułkach trzech regimentarzy, przyjmując liczby wg uchwalonych komputów (te podane w wykazie w nawiasach) - otrzymamy 8870. Pamiętać jednak należy, że do oddziałów państwowych należeli też arkebuzerzy Leszczyńskiego (150 koni), Kozacy Andrzeja Firleja (100 koni), poza tym w wojsku były dwie dodatkowe kompanie dragońskie (200 koni) i cztery kozackie (400 koni), których pod Zbarażem już nie było. Łącznie 9720. 250 wybrańców dopiero w trakcie odwrotu z Konstantynowa przyprowadził Kochanowski, ale 105 wybrańców wielkopolskich i bełskich mogło dołączyć wcześniej i również znaleźć się w kompucie. Wreszcie chorągiew Ponętowskiego została rozliczona wśród królewskich - to kolejne 100 koni przed ubytkami z czasu odwrotu. Dostajemy razem około 9925. Chorągwie kozacka i dragońska Lubomirskiego to zaciągi woj. krakowskiego i również one musiały być doliczone do wojska królewskiego. Tym sposobem otrzymamy już 10125 etatów. Możliwe jest również, że w kompucie był regiment pieszy Stanisława Latalskiego (400 osób), posłany później do Kamieńca, a brakowało kilku chorągwi, które przyszły później.

Z relacji Radwańskiego dowiadujemy się z kolei, że „Ochotnika/ było piękne grono. (Pewną trzecią część Woyska w Zbarażu liczono)”. ${ }^{135}$ Jednak przyjmując 6 tys. wojska królewskiego z relacji Firleja i odliczając 25\% na ślepe porcje $\mathrm{w}$ wojsku panięcym, liczącym 3284, otrzymujemy go tylko ok. 2463 do boju, a więc wyraźnie mniej niż 1/3 ogółu wojska. W dodatku list Firleja został napisany 7 lipca, a po tej dacie część uciekinierów z wojska królewskiego zapewne zdążyła wrócić do obozu - wg Białobłockiego na wieść o przyjściu Wiśniowieckiego do Wiśniowca „y ci co miiaią Obóz/ słysząc to/ nazad się wracaią". ${ }^{136}$ Wydaje się zatem, że jednostki prywatne

\footnotetext{
134 Архивъ Юго-Западной Россіи, издаваемый коммиссіею для разбора древнихъ актовъ, состоящей при Кіевскомъ, Подольскомъ и Вольнскомъ Генераль-Губернаторе, сz. 3, t. 4, Акты относящіеся къ эпохе Богдана Хмельницкаго (Київ: Лито-типогр. Императорскаго Университета Св. Владимира Акц. О-ва Н. Т. Корчакъ-Новицкаго, 1914), 284-285.

135 Radwański, Zbaraska Expeditia, C2v.

136 Klar męstwa, B2. Powroty uciekinierów potwierdzają pośrednio nowiny „Z Lublina d. 14 Julij 1649 r.”, 61-62, gdzie donoszą, że „w Glinianach Towarzystwa jest niemało z różnych chorągwi, którzy do obozu przebrać się nie mogąc [podkreślenie - M. R.] z Xciem P. Starostą, na szczęśliwsze oczekiwają nowiny”. Dalej list informuje o pierwszych walkach pod Zbarażem. „Xciem P. Starostą” był prawdopodobnie Michał Czartoryski, starosta krzemieniecki.
} 
zostały dokładniej rozliczone w czasie zapłaty żołdu. Niemniej i tak w pocztach panięcych było wyraźnie mniej niż $1 / 3$ z całego wojska.

Jak się zdaje, przed odwrotem spod Konstantynowa oddziały Firleja liczyły w wojsku królewskim 7 tys. żołnierza do boju - taka informacja trafiła do gońca moskiewskiego przebywającego później w Polsce, który obok 5 tys. polskich żołnierzy wyliczał $\mathrm{w}$ armii regimentarskiej „Niemiec pruskich najemnych pod 2000", a w później dołączonych oddziałach Wiśniowieckiego jeszcze 2 tys. żołnierzy. ${ }^{137}$

Reasumując, z 12824 lub nieco więcej stawek żołdu należy odliczyć tyle wakatów, by uzyskać 12 tys., a następnie jeszcze odliczyć od tej sumy ślepe porcje. Jednak od pocztów panięcych wakatów nie odliczamy, gdyż zdecydowana większość z nich przyszła z Wiśniowieckim i tym samym nie została uszczuplona przez dezercję, a liczby podane dla pozostałych chorągwi są mocno zróżnicowane i tym samym sugerują dokładniejsze obliczenie ich siły.

Jeśli chcemy więc poznać siłę rzeczywistą konkretnej wymienionej w spisie chorągwi, musimy najpierw sprawdzić, czy należy do zaciągów prywatnych, czy państwowych (państwowe to kwarciane, suplementowe, powiatowe, łanowe). Jeśli do prywatnych, wówczas odejmujemy $1 / 4$, jeśli do państwowych - najpierw odejmujemy uciekinierów, a następnie od pozostałych jeszcze 1/4. Oczywiście nie dotyczy to chorągwi, w których uwzględniono ubytki.

Wśród wspomnianych ok. 9 tys. żołnierzy samych jeźdźców było - licząc wg podanej metody - około 6,3 tys. (4280 z zaciągów państwowych i $2020 \mathrm{z}$ prywatnych). Kolejne 2,7 tys. żołnierzy stanowiłaby wtedy piechota i dragonia. Jednak zwrot "nie zupełne były chorągwie, osobliwie cudzoziemskie [wytłuszczenie - M. R.]"138 sugeruje nam, że stan oddziałów pieszych i dragońskich był jeszcze dalszy od etatowego niż wojsk narodowych. $\mathrm{Z}$ tego też powodu możemy spokojnie zaokrąglić siłę bojową wojsk koronnych do 6,5 tys. jazdy i 2,5 tys. piechoty z dragonami. Po ciężkich stratach poniesionych w czasie podjazdu 9 lipca, a także w dniach 10-13 i 16-17 lipca, około 18 lipca jazdy pozostało zapewne niewiele więcej niż 6 tys. - tak zdaje się wskazywać jeden z diariuszy obrony, który pod datą 18 lipca informuje: „Poniewasz tabor był wielki a do obrony ludzi mało było (bo nas pewnie nad 20 [lub 10, zapis niepewny - M.R.] tysięcy do obrony, a na szesc tysięcy do boiu nie bylo)". ${ }^{139}$ Możliwe, że do boju w polu autor diariusza li-

\footnotetext{
137 „Zapiska ruskiego gońca Kunakowa grudzień 1649,” w Воссоединение Украины с Россией. Документы и материалы в трех томах, t. 2, 1648-1651 годы (Москва: Изд. Академии Наук СССР, 1953), 300.

138 Pamiętniki Albrychta Stanisława X. Radziwiłła, 396.

139 Biblioteka PAU/PAN w Krakowie, rkps 2254, Księga pamiętnicza Jakuba Michałowskiego, t. 4, Acta Anni 1649 pod Zbarażem Nowym albo raczey Diarius, 359v. Diariusz ten wydany w zbiorze: Relacje wojenne, 135-162.
} 
czy samą jazdę. Co do oceny ogólnej liczebności sił polskich na 10 tys., taka liczba się pojawia także gdzie indziej. Przykładowo Jan Białobłocki twierdzi, że „nad dziesięć tysięcy coś było”. ${ }^{140}$

W kopiariuszu Marcina Golińskiego znajdują się informacje, że Wiśniowiecki po połączeniu z regimentarzami wybrał „siedm tisięcy woiska komonnego y uderzył na Pułky Kozacky y Tatarsky". ${ }^{141}$ To - w połączeniu z informacją o wyjściu wojska przed obóz 10 lipca - zdaje się wskazywać, że jazda polska mogła w początkowym okresie walk dochodzić nawet do 7 tys. Nie można jednak wykluczyć, że chodzi tu o stan etatowy sił, które uderzyły tego dnia na nadciągającego wroga.

Oprócz żołnierzy w armii polskiej była także liczna hołota obozowa. Znajdujemy zatem w źródłach liczby większe niż 12-13 tys. Zapisano tak na marginesie informacji o odsieczy dla „czterna[s]tu tysięcy wojska pod Zbarażem”. ${ }^{142}$ We współczesnych wydarzeniom nowinach czytamy, że „Obóz nasz teraz w Zbarażu rachują więcej niż 15 tysięcy”. ${ }^{143}$ Ta liczba również była znana. Przykładowo w latopisie $\mathrm{z}$ lat 1648-1653 znajdujemy informacje o „obozie polskim, w ktorym załedwie 15000 było żołnierza”. ${ }^{144}$

Dość liczne są wzmianki o 20 tys. obrońców. ${ }^{145}$ Tak też oceniano siły polskie w obozie kozackim 15 sierpnia, gdy przybył tam szpieg moskiewski. ${ }^{146}$

Mimo pozornego zamętu da się te liczby pogodzić, gdyż wiadomo o tym, że 10 lipca ubyło kilka tysięcy czeladzi posłanej po żywność i paszę, a pobitej, pojmanej i rozproszonej przez zagon nieprzyjacielski. ${ }^{147}$ Straty zamknęły się w przedziale 4-6 tys., określonym przez jeden z diariuszy. ${ }^{148}$ Wzmianka z poematu o tym, że nieprzyjaciele „na dwa na trzy tysiące Czeladzi na-

\footnotetext{
140 Klar męstwa, B4v.
}

141 ЛНБВС, OR, f. 5, о. 1, RBZNiO, sygn. II 189, [Notatka Marcina Golińskiego], b.m., b.d., 259.

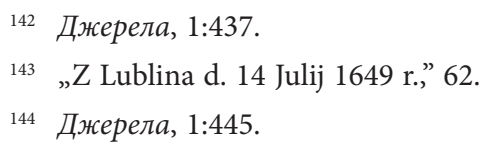

145 Biblioteka PAU/PAN w Krakowie, rkps 1275, Kronika rymowana wypadków politycznych w Polsce od r. 1648-1672, b.m., b.d., 12v, „z luźnymi było na dwadziścia tysięcy zrazu”. Albrycht Stanisław Radziwiłł, Pamiętnik o dziejach w Polsce, t. 3, (1647-1656), przeł. i oprac. Adam Przyboś i Roman Żelewski (Warszawa: Państwowy Instytut Wydawniczy, 1980), 205, „11-go tego miesiąca [lipca] Chmielnicki zamknął w oblężeniu naszych, których liczba sięgała 20000".

146 Акты, относящіеся къ исторіи Южной и Западной Россіи, собранные и изданные Археографическою Коммиссіею, t. 3, (1638-1657) (Санкт-Петербург: Въ типографіи П., 1861), 349-350. Ta sama relacja w: Воссоединение, 2:250.

147 „Akta Anni 1649 pod Zbarażem Nowym,” 136; BZNiO, MIO, CdAC, sygn. II 9538, Diariusz rzeczy w Woysku naszym a Decima octava Juny [1649], b.m, 5.

148 BJ, rkps 5, Dyariusz Żbaraskie ${ }^{\circ}$ Oblezenia 1649, b.m., b.d., 861. 
gle zabiraią" ${ }^{149}$ niekoniecznie musi być sprzeczna z podanym przedziałem, gdyż może oznaczać jedynie liczbę wziętych do niewoli.

Niecałą czeladź można liczyć jako potencjalnych obrońców, gdyż jej część stanowiły dzieci. Tych niezdatnych do walki była jednak tylko garstka. Oprócz wojska w obozie znalazło się także 6 tys. chłopów obojga płci, którzy schronili się tam przed Kozakami i Tatarami. ${ }^{150} \mathrm{Na}$ tyłach obozu znajdowało się też miasto, w którym było w 1583 r. 371 dymów. ${ }^{151}$ Licząc 6 głów na dym, dawałoby to ok. 2226 osób. W 1629 r., liczba dymów wynosiła już 518 (licząc w to Załuże i Stary Zbaraż), ${ }^{152}$ co przy podanym wyżej współczynniku dawałoby około 3108 mieszkańców. Do 1649 r. liczba mieszkańców musiała wzrosnąć. Jednak w roku 1648 Zbaraż został splądrowany przez rebeliantów. Jak bardzo zniwelowało to rozwój miasta między 1629 a 1648 r. - trudno stwierdzić. W każdym razie część mieszczan wzięła udział w obronie samego miasta, być może walczyła także jakaś grupa chłopstwa. W sumie więc na terenie miasta i obozu mogło się znaleźć ponad 24 tys. ludzi, ale w boju mogło wziąć udział niewiele więcej niż 15 tys.

Do powyższych uwag należy jeszcze dodać, że o ile uzbrojenie żołnierzy zawodowych było wysokiej jakości, to czeladź walczyła np. (a może głównie) kosami, których użycie jest poświadczone przy odpieraniu szturmu 13 lipca, kiedy to Kozacy atakujący od wody zostali „od ochotnika y od Czeladzi Wozowy dobrze zrażeni, częścią od strzelby y od kos wygubieny, częścią natopieni w stawie, ostatek uciekly zwłaszcza, gdy posiłek iezdny nastąpił". ${ }^{153}$ Interesująco wygląda podana dla sił polskich liczba wozów: 20 tys. W obozie było też 60 tys. koni. ${ }^{154}$ Wydaje się zatem, że przy 20 tys. wozów było ok. 40 tys. koni zaprzęgowych, a ponadto w obozie ok. 20 tys. koni bojowych i podjezdków (koni służących do przemieszczania się żołnierzy poza polem walki). Skoro czeladź przed utratą wysłanych 4-6 tys. mogła liczyć 11 tys., to znaczyłoby, że większa część służących musiała prowadzić po 2 wozy.

\footnotetext{
149 Biblioteka PAU/PAN w Krakowie, 1275, Kronika rymowana wypadków politycznych w Polsce od r. 1648-1672, b.m., b.d., 12v.

150 „Akta Anni 1649 pod Zbarażem Nowym,” 158.

151 Źródła dziejowe, t. 19, Polska XVI wieku pod względem geograficzno-statystycznym. Tom VIII. Ziemie ruskie. Wołyń i Podole opisane przez Aleksandra Jabłonowskiego (Warszawa: Skład główny w Księgarni Gebethnera i Wolffa, 1889), 127.

152 Олексій Іванович Баранович, Залюднення України перед Хмельниччиною: Волинське воєводство, cz. 1, Залюднення Волинського воєводства в першій половині XVII cm. (Київ: Всеукраінська Академія наук Комісия Історично-географічна, 1930), 98.

153 BZNiO, MIO, CdAC, sygn. II 9538, Diariusz rzeczy w Woysku naszym a Decima octava Juny [1649], b.m., 6.

154 Vimina, Historia delle, 145.
} 


\section{Parę słów o amunicji}

Warto nieco uwagi poświęcić zaopatrzeniu armii polskiej w amunicję. ${ }^{155}$ Znane na ten temat wiadomości są niestety szczątkowe i dotyczą jedynie amunicji i wyposażenia wysłanego do wojska $\mathrm{z}$ arsenału warszawskiego. I tak 18340 kul, które posłano za Ostrorogiem 13 grudnia 1648 r., zapewne w większej części wystrzelano w czasie kampanii podolskiej w lutym i marcu. Do regimentu Krzysztofa Przyjemskiego 29 grudnia 1648 r. posłano 4352 kule. Nie brał on udziału w żadnych starciach, więc powinien je mieć na początku oblężenia. 30 i 31 grudnia wysłano też Korfowi dwie kapy ołowiu i 25024 kule, z których większość zapewne wystrzelano w czasie walk na Podolu. Dalsze zapasy wysłano z Warszawy już w 1649 r. „18 Maia podczaszemu koronnemu [Ostrorogowi] do obozu 64 barełki, in summa 122880 kul" wydano. ${ }^{156}$ To oczywiście część z zapasów, jakie posiadało wojsko. W każdym razie zaopatrzenie obozu w amunicję okazało się wystarczające na długie oblężenie.

\section{Kwestia dowodzenia}

Teoretycznie naczelną komendę sprawował kasztelan bełski Andrzej (Jędrzej) Firlej będący regimentarzem wielkim. Miał on spore doświadczenie wojenne. Walczył już pod Smoleńskiem w 1610 r. (nie wiem, czy w roku poprzedzającym również), gdzie przejął chorągiew husarską po zmarłym kasztelanie przemyskim Stanisławie Stadnickim. Wielkim męstwem i sprawnością wsławił się jako rotmistrz tejże chorągwi pod Kłuszynem w roku 1610, był pod Oryninem w $1618 \mathrm{r}$. z nową chorągwią, wreszcie dowodził pułkiem pod Smoleńskiem w 1633 r., ${ }^{157}$ ale od tego czasu zdążył się znacznie postarzeć. Nie miał też doświadczenia jako wódz samodzielnej armii - z wyjątkiem krótkiego epizodu tuż przed samymi walkami zbaraskimi. Jego autorytet $\mathrm{w}$ wojsku nie był zatem zbyt wielki, o czym świadczy m.in. przebieg narady pod Konstantynowem 22 czerwca, gdy doszło do gorszących kłótni między nim a Stanisławem Lanckorońskim: „Nie zgadzaly się z sobą JP. Regimentarze ktorych dwa było tylko wtenczas, y miely rade $\mathrm{z}$ sobą nie bez

\footnotetext{
155 Jeszcze przed kampanią było z tym bardzo źle. Jak donosił listem z 5 maja Lanckoroński, „armaty ani wojennej municiej jeszcze żadnej nie mam”, cyt. za: Ojczyste spominki, 2:19.

156 Górski, Historya artyleryi, 293-294. Kapa nie miała, jak się zdaje, ściśle określonej wagi. Przedrukowany przez Górskiego dokument podaje także (s. 293) ciężar kapy: najpierw 8 kap ważących razem 81 cetnarów i 1 achtel, 10 kap ważących 85 cetnarów i 4 achtele, wreszcie 12 kap o wadze 115 cetnarów i 6 achteli. Wiedząc, że cetnar ważył 64,8 kg, a achtel stanowił 1/8 cetnara, otrzymujemy kapy ważące odpowiednio: 657, 554 i $625 \mathrm{~kg}$.

157 O dokonaniach Firleja: Katafalk Rycerski, 107-117, 121. O tym, co zrobił pod Kłuszynem, pisze Sikora, Kłuszyn 1610 (Warszawa: Wyd. Erica, 2010), 107.
} 
dissensiey samych siebie i Woyska". ${ }^{158}$ Spory wpływ na brak wystarczającego autorytetu Firleja miało z pewnością także to, że był on heretykiem z sekty kalwińskiej, gdy tymczasem większość rycerstwa stanowili katolicy - tradycyjnie niezbyt tolerancyjni dla innowierców.

Regimentarzem polnym był kasztelan kamieniecki Stanisław Lanckoroński, wreszcie trzecim regimentarzem podczaszy koronny Mikołaj Ostroróg. ${ }^{159}$

Wiele faktów wskazuje na to, że faktycznym lub przynajmniej równym z Firlejem dowódcą był książę Jeremi Wiśniowiecki. Przykładowo, gdy 11 lipca kniaź zganił kształt czy też wielkość obozu, niemal natychmiast przystąpiono do odcięcia części umocnień nowym wałem i to na odcinku Firleja właśnie. ${ }^{160}$ Gdy regimentarze chcieli 13 i 19 lipca wycofać się na zamek, książę na to nie pozwalał. ${ }^{161}$ Zresztą nawet w oficjalnej relacji Wiśniowiecki jest wymieniony jako hetman, a więc głównodowodzący: „Co wszystko dzielnością wytrzymali ci wszyscy co w oblężeniu byli/ ale nawięcey walecznego y nigdy niezrównanego w odwadze męża y hetmana [wytłuszczenie - M. R.]/ Jaśnie Oświeconego X. Michała Hieremiego Korybuta Wiśniowieckiego". ${ }^{162}$

Na zakończenie warto zaznaczyć, że niniejsze wyliczenie oddziałów polskich zostało oparte na znacznie wartościowszym źródle niż kronika Wespazjana Kochowskiego. Dotychczasowe wykazy (w tym mój poprzedni, zawarty w cytowanej książce) bazujące na tej kronice były zarówno niedokładne, jak i niepełne. Okazało się również, że i w wykazie uczestnika walk - porucznika „armatnego” Wojciecha Radwańskiego - zdarzyły się pewne potknięcia. Udało mi się także potwierdzić skład pułku wielkopolskiego, zrekonstruowany przez Bartosza Staręgowskiego.

\section{Bibliografia}

Archiwalia

Archiwum Główne Akt Dawnych w Warszawie

Akta Skarbowe Wojskowe

$158 \mathrm{BZNiO}, \mathrm{MIO}, \mathrm{CdAC}$, sygn. II 9538, Diariusz rzeczy w Woysku naszym a Decima octava Juny [1649], b.m., 3 .

159 B. Czart., rkps 1657, brak tytułu dokumentu, b.m, b.d., 560, „Regimentarzami byli JMP Firley Castelan Bełzky Generalis [wielkim] JMP Lanckoronsky Castelan Kamieniecky Campestris [polnym]".

160 BZNiO, MIO, CdAC, sygn. II 9538, Diariusz rzeczy, b.m., b.d., 5-6.

161 ЛНБВС, OR, f. 5, о. 1, RBZNiO, sygn. II 189, Żałosny Diarius Woyska koronnego którzy beli w oblężeniu pod Zbarażem w obozie od kozaków i Tatarów krimskych Anno Do: 1649, [zapewne Zbaraż], [1649 r.], 281-282.

162 Relacya Chwalebney expedyciey/ triumphalnego powodzenia/ szczęśliwego uspokoienia z nieprzyiaciołmi/naiaśnieyszego y niezwyciężonego monarchy Jana Kazimierza $z$ łaski bożey, króla polskiego y szwedzkiego,むc.むc. Roku 1650 (b.m.w.: b.w., 1650), C4v. 
Archiwum Narodowe w Krakowie

Akta Grodzkie Krakowskie

Księgi Grodzkie Bieckie

Archiwum Państwowe w Gdańsku

Bibliotheca Archivi

Recesy Stanów Zachodnio-Pruskich

Archiwum Państwowe w Lublinie

Zespół 8: Relationes

Archiwum Państwowe w Poznaniu

Komisja Skarbowa Poznańska

Księgi Grodzkie Poznańskie

Biblioteka Jagiellońska

Rękopisy

Biblioteka XX. Czartoryskich w Krakowie

Rękopisy

Teki Naruszewicza

Biblioteka Polskiej Akademii Umiejętności i Polskiej Akademii Nauk w Krakowie

Rękopisy

Biblioteka Uniwersytetu Wrocławskiego

Steinwehr II F 37 vol. 2

Biblioteka Zakładu Narodowego im. Ossolińskich

Manuscripta Instituti Ossoliniani, Collectio dr. A. Czołowski

Львівська національна наукова бібліотека України імені В. Стефаника

Rękopisy Biblioteki Zakładu Narodowego im. Ossolińskich

\section{Źródła wydane i starodruki}

Акты, относящіеся къ исторіи Южной и Западной Россіи, собранные и изданные Археографическою Коммиссіею. Т. 3, (1638-1657). Санкт-Петербург: Въ типографіи П., 1861.

Архивъ Юго-Западной Россіи, издаваемьий коммиссіею для разбора древнихъ актовъ, состоящей при Кіевскомъ, Подольскомъ и Волынскомъ ГенеральГубернаторе. Сz. 3, Т. 4, Акты относящіеся къ эпохе Богдана Хмельницкаго. Київ: Лито-типогр. Императорскаго Университета Св. Владимира Акц. О-ва Н. Т. Корчакъ-Новицкаго, 1914.

Borek, Piotr, oprac. „Arma cosacica”. Poezja okolicznościowa o wojnie polsko-kozackiej 1648-1649. Kraków: Collegium Columbinum, 2005.

Документы об освободительной войне украинского народа. 1648-1654 гг. Киев: Наукова думка, 1965.

Jabłonowski, Aleksander, oprac. Polska XVI wieku pod względem geograficzno-statystycznym. T. 8, Ziemie ruskie. Wołyń i Podole. Źródła dziejowe. T. 19. Warszawa: Skład główny w Księgarni Gebethnera i Wolffa, 1889.

Jabłonowski, Aleksander, oprac. Polska XVI wieku pod względem geograficzno-statystycznym. T. 9, Ziemie Ruskie. Ukraina (Kijów - Bracław). Źródła dziejowe. T. 20. Warszawa: Skład główny w Księgarni Gebethnera i Wolffa, 1894.

Jakuba Michałowskiego wojskiego lubelskiego, a później kasztelana bieckiego Księga Pamiętnicza. Kraków: Cesarsko-Królewskie Towarzystwo Naukowe Krakowskie, 1864. 
Katafalk Rycerski Wielmożnemu Jego Mośći Panu Mikołaiowi z Dambrowice Firleiowi Starościcowi Trembowelskiemu, Rotmistrzowi I. K. M. B.m, 1649.

Klar męstwa Na Obiaśnienie Pochodni. W dalsza droge ku nieugasłey Sławie Iaśnie Oświeconego Xiążęcia I. Mći, Ieremia Michała Korybvta na Wiśniowcu, y Łubniach Wisniowieckiego, Woiewody Rvskiego, Kaniowskiego, \& c. Starosty. Aż do wyprawy woienney pod Zborow Samego Naiaśnieyszego Monarchy Krola Iego Mosci Jana Kazimierza nam szczęśliwie panującego. We czterech także Częściach wydany przez tegoż Authora, w Miesiącu Wrześniu. Roku Pańskiego 1649. Kraków: Drukarnia Franciszka Cezarego I. K. M. Typogr., 1649.

[Kochowski, Wespazjan.] Annalium Poloniae ab obidu Vladslai IV. Climacter Primus. Scriptore Vespasiano a' Kochow Kochowski. Cracoviae: ex officina Georgii et Nicolai Schedel, po 3 II 1683.

Kochowski, Wespazjan. Historya panowania Jana Kazimierza przez nieznajomego autora wydana z rękopisu przez Edwarda Raczyńskiego. T. 1. Poznań: Walenty Stefański, 1840.

Konstitvcie seymv walnego koronnego sześćniedzielnego, warszawskiego Roku Pańskiego MDC.XLIX. Dnia 22 listopada. Warszawa: W Drukarniey Piotra Elerta J. K. M. Typographa, 1649.

Mytsyk, Jurij, red. Джерела з історії Національно-визвольної війни українського народу 1648-1658 рр. Т. 1, (1648-1649 рр). Київ: Інститут української археографії та джерелознавства ім. М.С. Грушевського, 2012.

Ojczyste spominki w pismach do dziejów dawnéj Polski, diaryusze, relacye, pamiętniki i.t.p. stużyć mogące do objaśnienia dziejów krajowych tudzież listy historyczne do panowania królów Jana Kazimiérza i Michała Korybuta oraz listy Jana Sobieskiego marszałka i hetmana wielkiego koronnego z rękopisów zebrane przez Ambrożego Grabowskiego. T. 2. Kraków: Józef Cyper, 1845.

Pamiętnik Mikołaja Jemiołowskiego, towarzysza lekkiej choragwi, ziemianina województwa bełzkiego, obejmujący dzieje Polski od roku 1648 do 1679 spółcześnie, porządkiem lat opowiedziane. Lwów: Drukarnia Zakładu Narodowego im. Ossolińskich, 1850.

Pastorius, Joachim. Bellum scythico cosacicum, seu de coniuratione Tartarorum, Cosacorum et plebis Russicae contra Regnum Poloniae. Dantisci: Sumptibus Georgy Fortisci S.R.M.Bibliopolae, 1652.

Przyłęcki, Stanisław, wyd. „Rodowód Domu Koniecpolskich.” W Pamiętniki o Koniecpolskich. Lwów: Nakł. Leona Rzewuskiego, 1842.

Raczyński, Edward, wyd. Pamiętniki Albrychta Stanisława X. Radziwiłła kanclerza w. litewskiego. Poznań: Bracia Szerk, 1839.

Radwański, Wojciech. Zbaraska Expeditia Poważna y Sławna. \& Oblężenie Zbaraskie Niestychane zdawna. Przez iednego z Radwanów, y Herbu Radwanu, Podana do wiadomości wszelakiego Stanu. Warszawa, 1649.

Radziwiłł, Albrycht Stanisław. Pamiętnik o dziejach w Polsce. T. 3, (1647-1656). Przeł. i oprac. Adam Przyboś i Roman Żelewski. Warszawa: Państwowy Instytut Wydawniczy, 1980.

Relacya Chwalebney expedyciey/ triumphalnego powodzenia/ szczęśliwego uspokoienia z nieprzyiaciołmi/naiaśnieyszego y niezwyciężonego monarchy Jana Kazimierza z łaski bożey, króla polskiego y szwedzkiego, \&́c.\&́c. Roku 1650. B.m.w: b.w., 1650. 
Theatrum Europeaum. T. 6, Theatri Europaei oder Historischer Deschreibung der denckwürdiger Geschichten vom Jahr Christi 1647 biß 1651. Frankfurt am Main: Matthaei Merians Seel. Erben/ Druckts Daniel Fievet, 1663.

Vimina, Alberto. Historia delle guerre civili di Polonia divisa in cinque libri progressi dell'armi Moskowite contro Polacchi. Venezia: Appresso Gio: Pietro Pinelli, 1671.

Volumina Legum. T. 4. Petersburg: Jozafat Ohryzko, 1860.

Воссоединение Украины с Россией. Документы и материалы в трех томах. Т. 2, 1648-1651 годы. Москва: Изд. Академии Наук СССР, 1953.

\section{Opracowania}

Andrzejczak, Dariusz. Kampania zbaraska 1649 roku. Toruń: Wyd. Adam Marszałek, 2012.

Frąś, Ludwik. Obrona Zbaraża w r. 1649. Kraków: b.w., 1932.

Górski, Konstanty. Historya artyleryi polskiej. Warszawa: Wende E. i Spółka, 1902.

Górski, Konstanty. Historya piechoty polskiej. Kraków: Księgarnia Spółka Wydawnicza Polska, 1893.

Nagielski, Mirosław. Relacje wojenne z pierwszych lat walk polsko-kozackich powstania Bohdana Chmielnickiego okresu „Ogniem i mieczem” (1648-1651). Warszawa: „Viking”, 1999.

Piwarski, Kazimierz. „Votum hetmana Hieronima Lubomirskiego na sejmie lubelskim w 1703 r." Przegląd Historyczno-Wojskowy 6, z. 1 (1933): 108-117.

Przyboś, Adam, wyd. Akta sejmikowe województwa krakowskiego. T. 2. Kraków: Nakładem Polskiej Akademii Umiejętności, 1953.

Rogowicz, Marek. „Bitwa pod Konstantynowem, 26-28 lipca 1648 roku.” Przeglad Historyczno-Wojskowy 18 (69), nr 2 (260) (2017): 11-44.

Rogowicz, Marek. Bitwa pod Zbarażem 1649. Oświęcim: Napoleon V, 2013.

Rogowicz, Marek. „Skład sił polskich nad Żółtymi Wodami i pod Korsuniem w 1648 roku." Przegląd Historyczno-Wojskowy 16 (67), nr 2 (252) (2015): 39-62.

Rybarski, Roman. Skarb i pieniądz za Jana Kazimierza, Michała Korybuta i Jana III. Warszawa: Towarzystwo Naukowe Warszawskie, 1939.

Sawczyński, Adam. „Płaca pocztom panięcym w1650.” Przegląd Historyczno-Wojskowy 9, z. 1 (1936): 119-125.

Sikora, Radosław. Husaria pod Wiedniem 1683. Warszawa: Wyd. Erica, 2012.

Sikora, Radosław. Kłuszyn 1610. Warszawa: Wyd. Erica, 2010.

Staręgowski, Bartosz. „W służbie województwom wielkopolskim i Rzeczypospolitej. Okoliczności sformowania i działalności pułku Bogusława Leszczyńskiego w latach 1648-1649." Res Historica, nr 44 (2017): 33-61. http://dx.doi.org/10.17951/ rh.2017.44.33-61.

Śledziński, Kacper. Zbaraż 1649. Warszawa: Bellona, 2005.

Tomkiewicz, Władysław. Jeremi Wiśniowiecki (1612-1651). Warszawa: Nakładem Towarzystwa Naukowego Warszawskiego, 1933.

Wimmer, Jan. Wojsko polskie w drugiej połowie XVII wieku. Warszawa: Wyd. Ministerstwa Obrony Narodowej, 1965. 


\section{STRESZCZENIE}

\section{Marek Rogowicz, Siły polskie pod Zbarażem 10 lipca 1649 r.}

Niniejsze opracowanie dotyczy określenia dokładnego składu etatowego sił polskich broniących Zbaraża, począwszy od 10 lipca 1649 r., a także ogólnej liczebności sił nadających się do walki w polu i do obrony obozu, wraz ze służbą obozową. Temat ten był poruszany już wcześniej, ale nie tak precyzyjnie i częściowo błędnie. Skład etatowy autorowi udało się ustalić w przybliżeniu na 12824 konie i osoby w 134 chorągwiach, łącznie 8938 jazdy oraz 3886 pieszych i dragonów. Po odliczeniu części ubytków związanych z dezercjami poprzedzającymi walki zbaraskie, których nie wzięto pod uwagę przy obliczaniu należnego wojsku żołdu, otrzymamy liczbę 12 tys. etatów. Po odliczeniu ślepych porcji daje to szacunek ok 9 tys. żołnierza do walki w polu. W źródłach występują też liczby 8 tys. i 10 tys., które można odnosić do tej kategorii obrońców. Liczby wyższe dotyczą liczebności wojska wraz ze służbą obozową, a zatem liczby obrońców możliwej do wykorzystania przy obronie obozu. W źródłach spotykamy także liczby 14 i 15 tys., a liczba jeszcze wyższa - 20 tys. odnosi się do liczebności wojska przed rozbiciem i/lub odcięciem od obozu 4-6 tys. czeladzi wysłanej w celu aprowizacji.

Słowa kluczowe: Powstanie Chmielnickiego, Zbaraż 1649 r., liczebność wojsk

\section{SUMMARY}

\section{Marek Rogowicz, The number of Polish forces at Zbaraż on $10 \mathrm{July,}$} 1649.

This study attempts to determine the exact full-time composition of the Polish forces that defended Zbaraż during the siege of the city that began on 10 July, 1649. as well as the general number of Polish forces that were available, which includes troops suitable for field combat and those assigned to camp duties. Previous studies concerning this topic have been imprecise and at times used incorrect evidence. The full-time composition of the Polish forces is estimated by the author of the article to total 12,824 soldiers serving under 134 banners, comprising of 8,938 cavalry and 3,886 infantry. After deducting the troops that deserted prior to the fighting, who were not considered when calculating the pay due to the army, the figure is reduced to 12,000 full-time soldiers. After deducting the non-combatants, the number of troops available to fight in the field is estimated at 9,000. Several sources provide similar estimates of the battlefield strength of the Polish contingent, i.e. 8,000 and 10,000 , the latter figure, however, probably includes those troops that were assigned to the defence of the camp. In other sources estimates of 14,15 and even as high as 20,000 can be found, these however refer to the size of the army before its part (4 to 6000 ) sended for provisioning was crushed and or cut off from the camp.

Keywords: Chmielnicki Uprising, Zbaraż 1649, number of troops 


\section{АННОТАЦИЯ}

\section{Марек Рогов ич, Польские силы под Збаражем 10 июля 1649 г.}

Данное исследование касается определения точного постоянного состава польских войск, защищающих Збараж начиная с 10 июля 1649 г., а также общей численности войск, пригодных для ведения боевых действий и для защиты лагеря, включая лагерные службы. Эта тема уже поднималась ранее, но не так точно и от части некорректно. Штатный состав автору статьи удалось оценить примерно в 12824 лошадей и людей в 134 хоругвях, всего 8938 конниц и 3886 пеших солдат и драгунов. После вычета некоторых потерь, связанных с дезертирством, предшествовавшим збаражским битвам, которые не были учтены при подсчете причитающихся армии выплат, мы получим 12 тысяч ставок. После вычета „слепых” ставок можно говорить о примерно 9000 солдат, готовых к полевым битвам. В различных источниках встречаются цифры 8000 и 10000 человек, которых можно отнести к этой категории защитников. Большие цифры могут принимать во внимание, кроме самой армии, еще и лагерные силы, то есть в целом они относятся ко всем защитникам, которые могут сражаться во время обороны лагеря. В источниках встречаются также цифры 14 и 15 тысяч, а самая крупная цифра - 20 тысяч - относится к численности армии перед разгромом 4-6 тысяч человек, отправленных за пополнением запасов.

Ключевые слова: Хмельницкое восстание, Збараж 1649 г., численность войск 